\title{
Chromium uptake, distribution and loss in the mussel Mytilus edulis: a structural, ultrastructural and microanalytical study
}

\author{
Colette Chassard-Bouchaud ${ }^{1}$, Jean François Boutin ${ }^{2}$, Philippe Hallegot $^{3}$, \\ Pierre Galle ${ }^{4}$
}

\footnotetext{
${ }^{1}$ Laboratoire de Biologie et Physiologie des Organismes marins, Université Pierre et Marie Curie, 4, place Jussieu, F-75252 Paris Cedex 05, France, and Centre de Microanalyse appliquée à la Biologie, 6 rue du Général Sarrail, F-94000 Créteil, France

${ }^{2}$ Service mixte de Contrôle Biologique, B. P. 16, F-91311 Montlery Cedex, France

${ }^{3}$ The University of Chicago, the Enrico Fermi Institute, 5640 Ellis Avenue, Chicago, Illinois 60637, USA

${ }^{4}$ Laboratoire de Biophysique de la Faculté de Médecine, 6 rue du Général Sarrail, F-94000 Créteil, France
}

\begin{abstract}
Several microanalytical techniques were used to assess the distribution and chemical form of chromium in various tissues of Mytilus edulis, at the cellular and subcellular levels. After $2 \mathrm{wk}$ exposure to $\mathrm{Cr}$ (III) salt ( $\mathrm{Cr}$ occurs principally in the trivalent state in the natural environment), investigations were performed on mussels. using secondary ion mass spectrometry (ion microscope and ion microprobe) associated with photon microscope, and X-ray spectrometry (electron microprobe) associated with transmission electron miscroscope. Cr measurements gave the following: kidney and gills exhibited the highest values, intermediate values were found for muscle and byssus (where Cr was adsorbed onto the threads and was incorporated within them), and lowest values were found in the digestive gland. Cr was also detected in the amoebocytes but not in the reproductive cells. The target organelle of $\mathrm{Cr}$ accumulation was shown to be the lysosome where the metal was associated with phosphorus and sulfur and trapped in an insoluble form. The significance of these different data is discussed. Cr kinetics of metabolism was compared between mussels and other aquatic organisms. Comparison in $M$. edulis of $\mathrm{Cr}$ metabolism with metabolism of other metals leads to the conclusion that $\mathrm{Cr}_{\mathrm{r}}$ is metabolised and transported differently from most toxic metals.
\end{abstract}

\section{INTRODUCTION}

Chromium ( $\mathrm{Cr}$ ) is one of the few elements of the periodic table which can affect mankind in all of the following 3 ways: (1) as an important material used in technology; (2) as a toxicant in food chains and to man, the final consumer, due to anthropogenic activity or to natural sources in the environment; and (3) as an essential component for biological and physiological functions such as the maintenance of normal glucose tolerance (Mertz 1969). Worldwide inventories of industrial discharges of $\mathrm{Cr}$ into the aquatic ecosystem show that anthropogenic input of $\mathrm{Cr}$ reaches a median value of about 142000 tonne $\mathrm{yr}^{-1}$ in comparison with 138000 tonne $\mathrm{yr}^{-1}$ for lead (Nriagu \& Pacyna 1988).

Valence state, chemical form, or exposure levels have to be taken into account when studying its toxicity. Cr occurs in the natural environment almost exclu- sively in the trivalent state and its concentration in seawater ranges between 0.3 and $0.6 \mathrm{ppb}$ (Riley \& Chester 1971). Because of the high energy required for oxidation to the hexavalent form, the latter is always a product of man's activity. Hexavalent compounds will ultimately be reduced to the trivalent state which is the biologically active state, whereas hexavalent $\mathrm{Cr}$ is much more toxic. $\mathrm{Cr}$ compounds differ greatly in their ability to penetrate cellular membranes. Cr may be found in living organisms only in bound form (Günter et al. 1974). Only trivalent $\mathrm{Cr}$ forms complexes with proteins, and biological activity occurs only after reduction of hexavalent $\mathrm{Cr}$ to the trivalent form (Schwartz \& Mertz 1959). When Cr VI enters the organism in ionic form, it is distributed in the same form among the organs and tissues where it is then reduced to the trivalent form and remains firmly bound. 
The ability of marine organisms to accumulate $\mathrm{Cr}$ substantially in excess of ambient seawater levels is well documented (Fukai \& Broquet 1965). The available data are of particular interest concerning filterfeeding bivalves which are well known for their ability to reflect environmental levels of trace metal contaminants in marine ecosystems. It is established that the mussel Mytilus edulis can concentrate metals (Bryan 1980) and various governmental agencies have adopted this species as a bioindicator of heavy metal pollution. $M$. edulis has several characteristics of a good indicator species, including the ability to accumulate high metal concentrations without dying, a sedentary way of life, high numerical abundance and an ability to adapt to laboratory conditions. The available data on $\mathrm{Cr}$ concentration in marine organisms shows large variability, particularly in $M$. edulis: measurements on whole soft tissues range between 0.3 and 49 ppm (dry weight) (Karbe et al. 1977, Lande 1977). Five species of bivalves from Greek waters were shown to contain between 16000 and 260000 times more $\mathrm{Cr}$ than seawater (Papadopoulu 1973)

Available data concerning $\mathrm{Cr}$ kinetics of concentration in mussels generally consider soft parts in totality and do not consider each organ separately (SchulzBaldes et al. 1983). Tissues are intermingled and on the same histological section of a mussel, one can commonly observe mantle, digestive and reproductive cells. Consequently, there is a need for investigations to be performed at the cell and organelle levels to obtain a more precise knowledge of Cr metabolism in the mussel.

$\mathrm{Cr}$ salts are active at low concentrations and are toxic to fish, for example at a 0.1 ppm dose (Strik et al. 1975). Thus, investigations on this metal require specially equipped laboratories with very sensitive analytical instrumentation. Analytical methods commonly used are inadequate: absorbed and unabsorbed elements cannot be distinguished and generally large quantities of biological material are needed, as well as long-term investigations. The available micro-analytical techniques are more suitable (Chassard-Bouchaud 1987). Secondary ion mass spectrometry (SIMS) and $\mathrm{X}$-ray spectrometry enable simultaneous morphological and chemical identifications to be made in histological sections. Although X-ray microanalysis is the most often used method, many biological problems cannot be solved because of its relatively low sensitivity and inability to detect very light elements, but an advantage is that observations at the ultrastructural level are possible. The main advantage of SIMS as applied in biological research is its very high sensitivity, of the order of 1000 to 10000 times that of the electron microprobe. Moreover, it is possible to obtain images representing the distribution of all the ele- ments of the periodic table, even when the concentration is very low ( $\left.\leqslant 0.1 \mathrm{ug} \mathrm{g}^{-1}\right)$, and to obtain isotopic measurements. In addition, digital processing of imagges associated with secondary ion microscopy has been recently developed (Cavellier et al. 1988); this post-acquisition image processing allows image enhancement or reconstruction, as well as multi-image correlation.

We were able to demonstrate that these microanalytical techniques are particularly useful for investigations in marine toxicology (Chassard-Bouchaud 1988). We obtained preliminary data on cellular and subcellular aspects of $\mathrm{Cr}$ concentration by the mussel Mytilus edulis (Chassard-Bouchaud \& Galle 1988). The purpose of this report is to present more extensive results on the uptake, distribution and loss of this metal, in the same species, at the structural and ultrastructural levels. Since $\mathrm{Cr}$ occurs in the natural environment, principally in the trivalent state, it seemed of interest to investigate its possible cytotoxicity.

\section{MATERIALS AND METHODS}

Biological material. Mature specimens of Mytilus edulis (L.) with a size range of 40 to $50 \mathrm{~mm}$ were collected from coastal waters of Brittany (Roscoff, France). Ten groups of 4 mussels were kept in aquaria with $4 \mathrm{l}$ of aerated sea water $\left(36 \%\right.$ salinity) at $12{ }^{\circ} \mathrm{C}$. Mussels were exposed to chromium chloride $\left(\mathrm{CrCl}_{3}\right)$ at a concentration of $10 \mathrm{mg} \mathrm{l}^{-1}$ for $2 \mathrm{wk}$. During the experiments, both the water and the metal were changed daily. The mussels were then dissected to separate the different tissues, which then underwent several treatments depending on the microanalytical technique to be used.

For SIMS, tissues were fixed chemically in Carnoy's fixative, embedded in paraffin, cut to sections $(5 \mu \mathrm{m})$ and deposited on a highly pure gold specimen holder, with removal of paraffin. Alternatively, cryofixation was performed with isopropane and then liquid nitrogen, and sections were deposited on the gold specimen holder. Results obtained using this second technique were similar to those obtained with the first one, but images were much better from chemically fixed samples due to flatness of the sections.

For X-ray spectrometry, samples were fixed in $2.5 \%$ glutaraldehyde in $0.2 \mathrm{M}$ sodium dimethylarsinate buffer at $\mathrm{pH} \mathrm{7.0.} \mathrm{After} \mathrm{washing} \mathrm{with} \mathrm{the} \mathrm{buffer,} \mathrm{the}$ samples were dehydrated and embedded in Epon. Ultrathin sections were then deposited on copper grids and coated with carbon. Grids to be observed in electron microscopy were stained (uranyl acetate and lead citrate) while grids to be examined with the electron microprobe were unstained. 
Cryofixation and both chemical fixations were made on each tissue of the 40 samples.

The gills, labial palps, digestive gland, kidney, byssal threads, muscle and gonads of control and Cr-exposed Mytilus edulis were examined by photon and by trans-

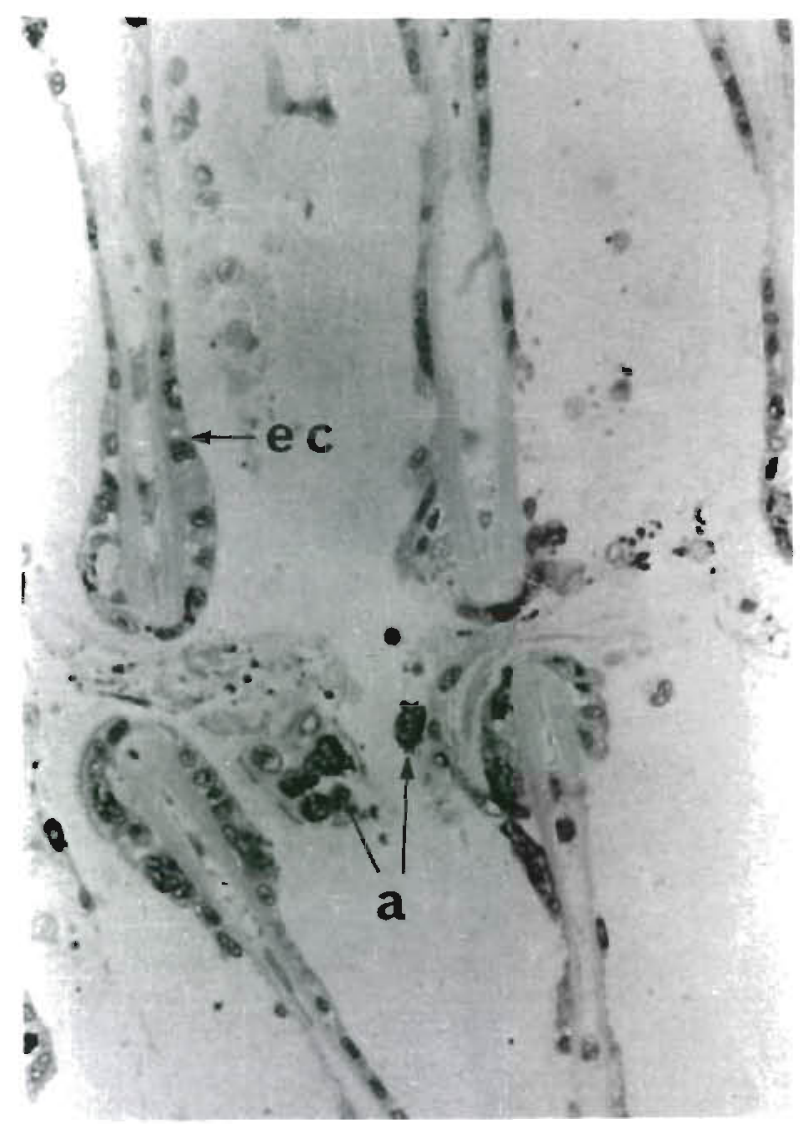

Fig. 1 Mytilus edulis. Cr-exposed gill. Photon micrograph of semithin cross-sections of filaments; ec: endothelial cells. Interfilament spaces are invaded by granular amoebocytes (a); $\times 800$ mission electron microscopy. Simultaneously, metal analyses of each tissue were performed at the structural level, using secondary ion mass spectrometry (ion microscope and ion microprobes) and at the ultrastructural level, using X-ray spectrometry (electron microprobe).

Instrumentation. Electron microscopy: A Philips EM 300 transmission electron microscope was used to study the ultrastructural morphology of tissue sections.

Secondary ion mass spectrometry: SIMS was performed, using the ion microscope and ion microprobes.

Ion microscope. The ion microscope (CAMECA IMS 300) was equipped with an electrostatic deflector, with
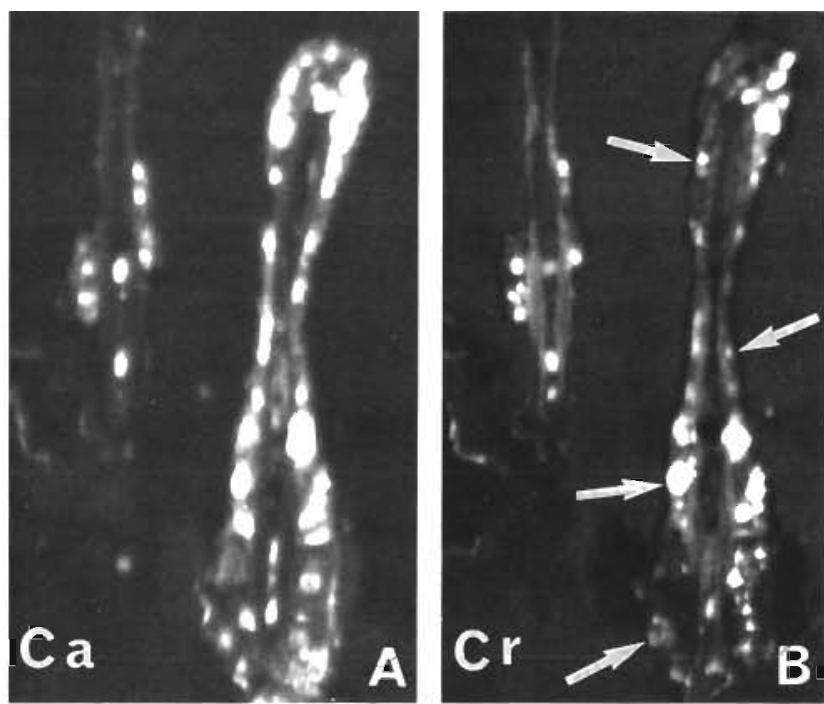

Fig. 2. Mytilus edulis. Cr-exposed gill. Ion microscope micrograph of a semithin cross section of filaments. (A) ${ }^{40} \mathrm{Ca}^{-}$image showing topography of the section; $\times 800$. (B) ${ }^{52} \mathrm{Cr}^{+}$image obtained from the same area as (A) showing the high $\mathrm{Cr}$ emission (arrows). Bright small points correspond to lysosomes; $\times 800$
Fig. 3. Mytilus edulis. Cr-exposed gill. Ion microprobe spectrum showing the 4 stable isotopes of chromium ( $\star$ ) at the masses: $50 \quad(4.31 \%), 52$ (major isotope $83.76 \%), 53(9.55 \%)$ and $54(2.38 \%)$ Note the presence of titanium isotopes $(\bullet)$ and gallium isotopes: $69(60.40 \%)$ and $71(39.60 \%)$ due to liquid gallium primary ion source

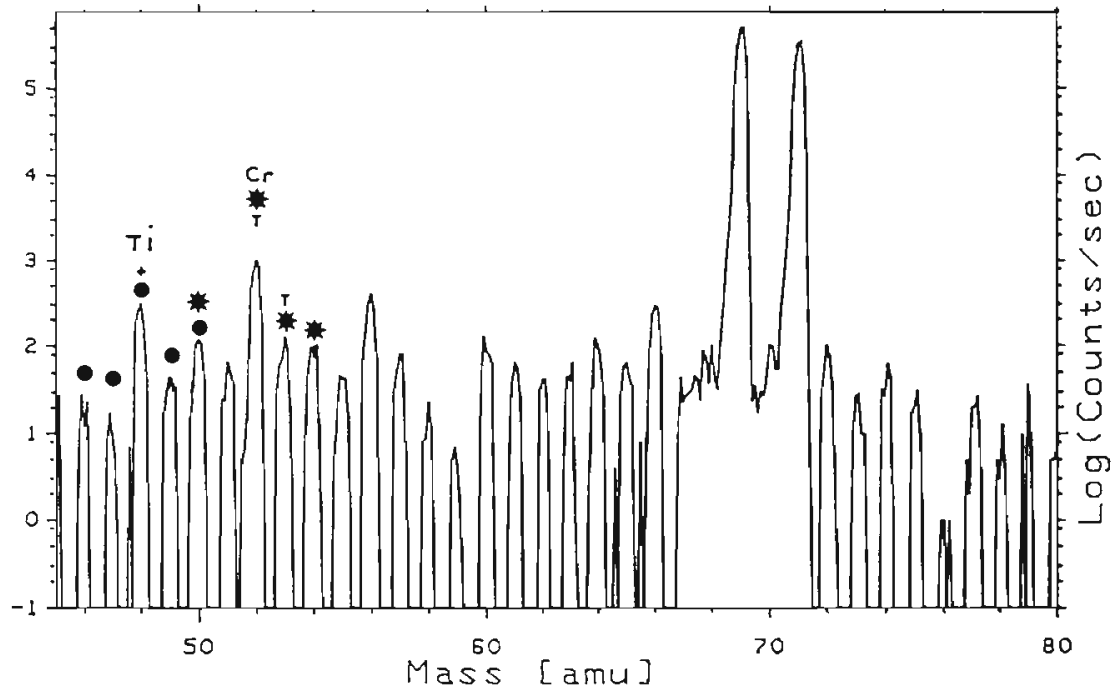


$\mathrm{O}_{2}{ }^{+}$as primary ions. The images of the distribution of the secondary ions were obtained directly with appropriate ion optics. Ion microscopy imaging, giving $\mathrm{Cr}$ distribution in the tissue sections. was performed by a beam of uniform density bombarding a large area (250 um) with a spatial resolution of $0.5 \mathrm{\mu m}$. The analytical conditions were previously described (ChassardBouchaud \& Galle 1988). High resolution mass spectra were obtained at mass 52 (Cr major isotope), in order to make the distinction between ${ }^{52} \mathrm{Cr}^{+}$ion and polyatomic ions (principally CaC: $40+12$ ).

Ion microprobes. Two types of instruments were used.

A RIBER MIQ 256 ion microprobe (Outrequin et al. 1988 ) with its associated equipment including a pollution-free ultrahigh vacuum system, was used with 2 different ion sources: liquid metal gallium was the primary ion for the study of positive secondary ions and cesium the primary ion for the study of negative secondary ions. Secondary ions were examined with a high-sensitivity quadrupole mass spectrometer. The surface of the specimen was scanned by a focused primary ion beam to obtain images: a point to point image of the ion-emitting spot was obtained with a spatial resolution defined by the size of the probe $(0.2$ to $2 \mu \mathrm{m})$.

A 40-60 keV SIM (Scanning Ion Microprobe) (UCHRL-SIM) was developed by the University of Chicago, in collaboration with the Hughes Research Laboratories (Levi-Setti et al. 1988). This instrument allows demonstration of topographic and elemental imaging with lateral resolution attaining $20 \mathrm{~nm}$. Using finely

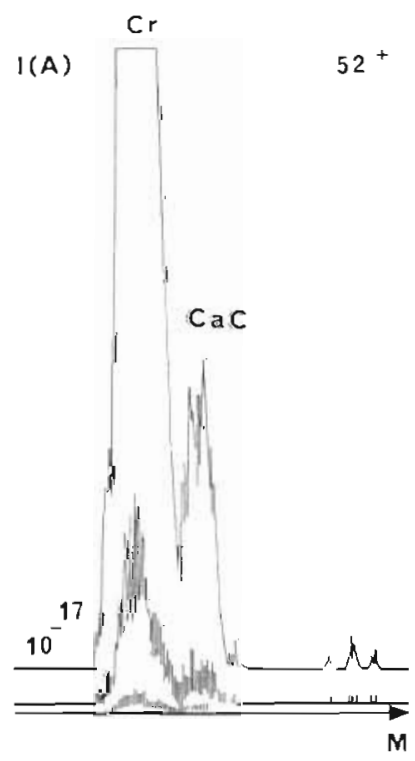

Fig. 4. Mytilus edulis. Cr-exposed gill. Ion microscope spectrum. High mass resolution at $52^{+}$showing presence of $\mathrm{Cr}$ and a small contribution of polyatomic ions $\mathrm{CaC}$. I: intensity (amperes); $M$ : mass focused beams from a liquid metal ion source (Ga), it is possible to routinely obtain topographic and elemental image resolution well below $0.1 \mathrm{~km}$, with a high sensitivity

$X$-ray spectrometry: A CAMEBAX microprobe, associated with a transmission electron microscope,
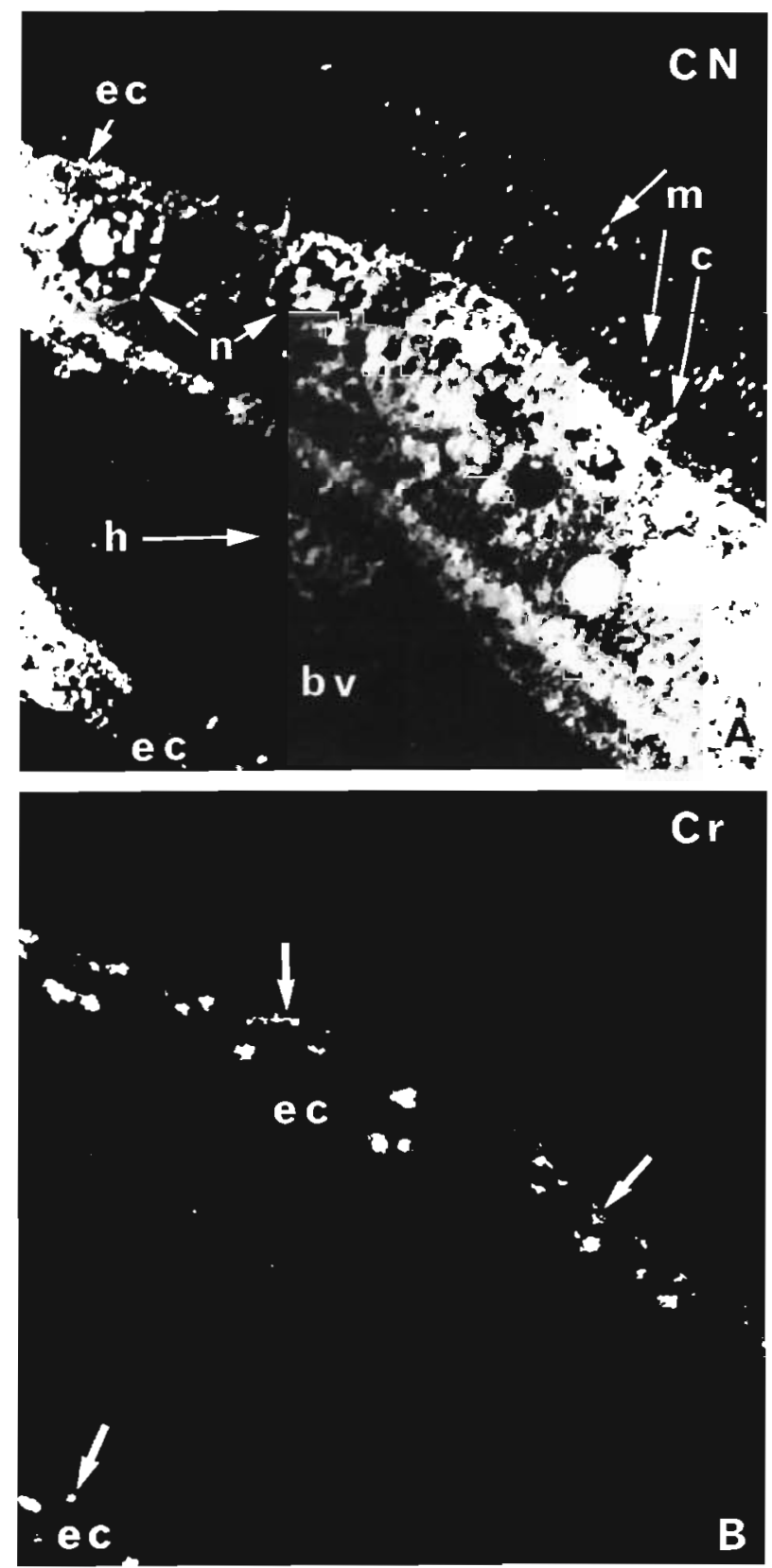

Fig. 5. Mytilus edulis. Cr-exposed gill. Ion microprobe micrographs of semithin section of filament. (A) ${ }^{26} \mathrm{CN}^{-}$image showing the topography of the section: epithelial cells (ec) with nuclei (n), microvulli (m) and cilia (c). Note the presence of haemocyte $(h)$ in the branchial vein (bv); $\times 2000$. (B) ${ }^{52} \mathrm{Cr}^{+}$ image obtained from the same area as (A), showing the high chromium emission from points which correspond to lysosomes (arrows) of the epithelial cells; $\times 2000$ 


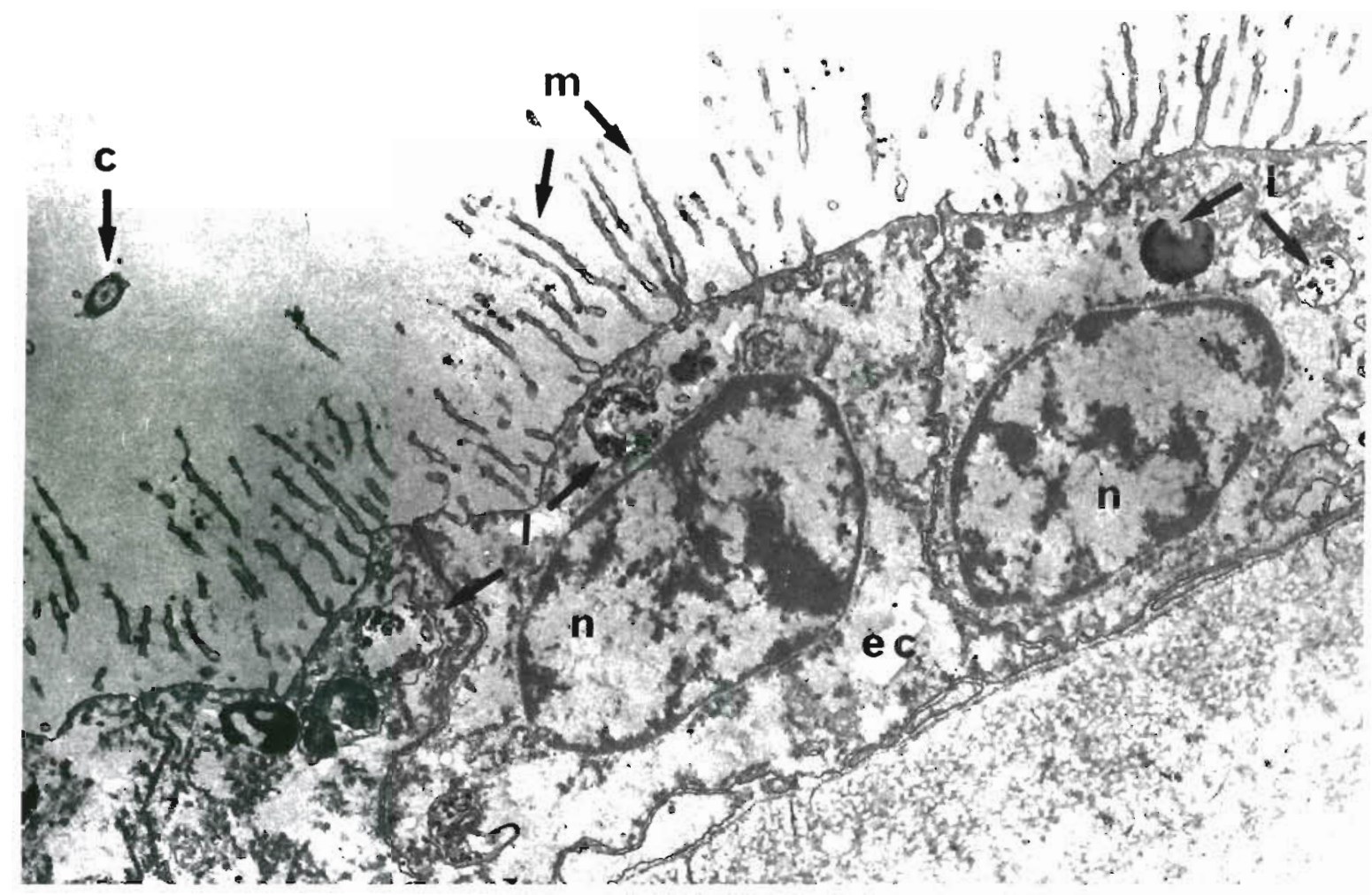

Fig. 6. Mytilus edulis. Cr-exposed gill Electron micrograph of flament showing epithelial cells (ec) with nuclel (n), clla (c) and microvilli (m). Lysosomes (l) contan dense microgranules of C.r. P and S, $\times 16400$

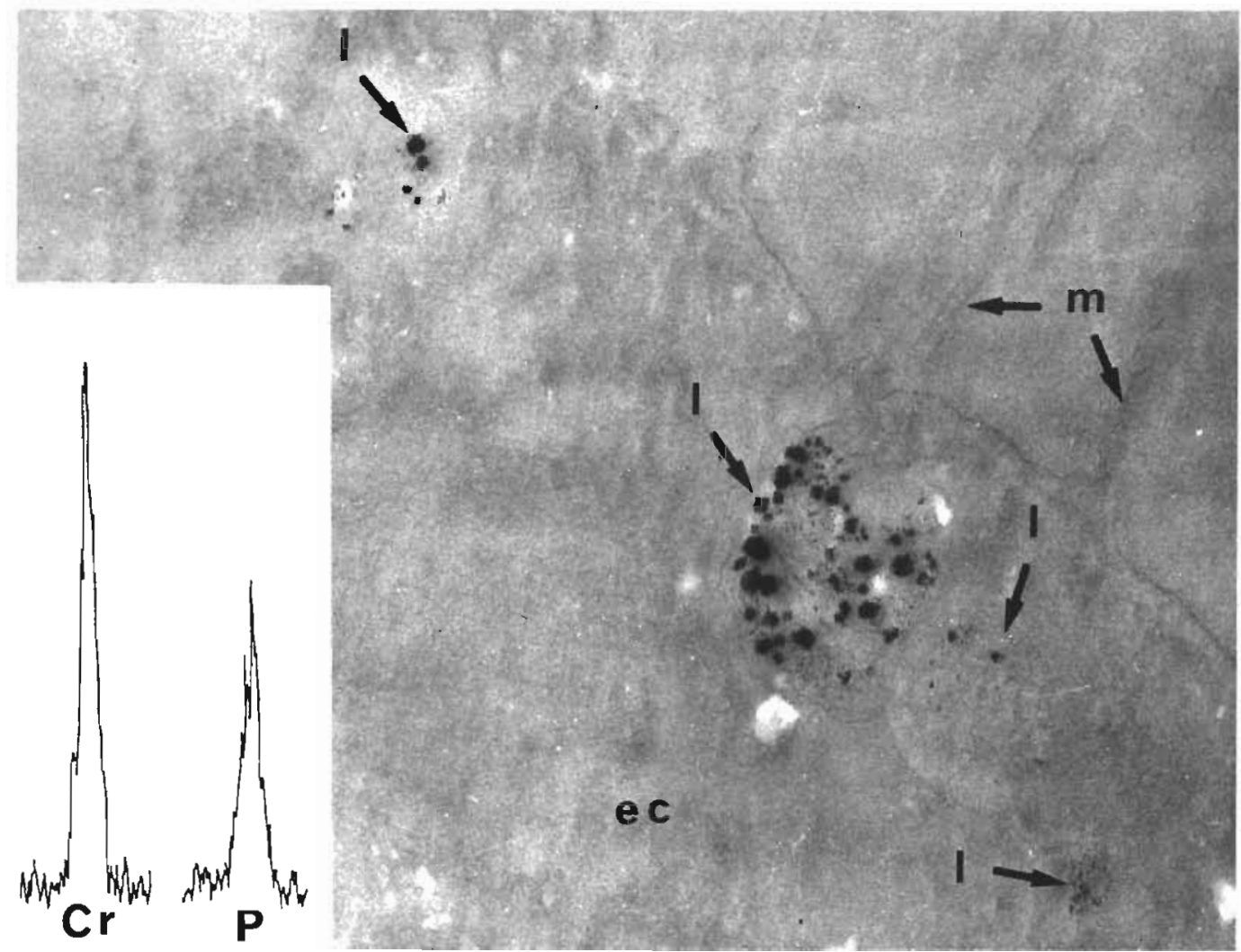

Fig. 7. Mytilus edulis. Cr-exposed gill. Electron micrograph of filament (non-osmicated and unstaned materal) showing an epithelial cell (ec) containing lysosomes (l) with dense microgranules of $\mathrm{Cr}$, P and $\mathrm{S}$; m microvilli. Inset. X-ray emission spectra of $\mathrm{Cr}$ and $\mathrm{P}(\mathrm{K}$, line $)$ obtained from these lysosomes, $\times 40000$ 
was used to identify elements within ultrathin sections. It was equipped with 2 wavelength-dispersive spectrometers fitted with the following crystals: TAP, ODPB, PET and LIF. The following operating conditions were used: $20 \mathrm{kV}$ accelerating voltage, $100 \mathrm{nA}$ probe current, $50 \mathrm{~nm}$ probe diameter

In addition, we estimated the relative metal concentration in the intracellular organelles, by determining the number of counts from the $\mathrm{K}_{\alpha}$ line of $\mathrm{Cr}$, phosphorus (P) and sulfur (S), over $50 \mathrm{~s}$. Counts on 20 organelles of 10 individuals were used to obtain the mean of each measurement. The background was determined by shifting the spectrometer to both sides of the line

Post-acquisition image processing: A NUMELEC PERICOLOR 2001 was used for multi-image correlation. This instrument, a multiprocessor and multibus system equipped with high capacity memories, was used in association with the ion microscope CAMECA IMS 300 and a NOCTICON camera (LHESA Electronique). This camera was fitted to the ion microscope, to film the fluorescent screen through the viewing window, using a luminous (f/2.2) $100 \mathrm{~mm}$ objective mounted between 2 telescopic tubes which allows adjustment of focus and magnification and thus maintains microscope resolution.

\section{RESULTS}

Gills

A photon micrograph (Fig. 1) shows abfrontal ends from 2 opposite lamellae of Cr-exposed samples. Interfjlament spaces were invaded by amoebocytes. Atrophy and deformation of cells were observed.

Ion micrographs, using the ion microscope, were obtained from the same semi-thin sections of Crtreated filaments shown in Fig. 1. They show the calcium distribution (Fig. 2A) which gives the topography of the section and the Cr distribution (Fig. 2B) from the same area of tissue. Low resolution mass spectra (Fig. 3) were obtained from these $\mathrm{Cr}$-exposed gill sections and all stable isotopes of $\mathrm{Cr}$ were identified ${ }^{50} \mathrm{Cr}^{+}$ $(4.31 \%),{ }^{52} \mathrm{Cr}^{+}(83.76 \%$, major isotope $),{ }^{53} \mathrm{Cr}^{+}(9.55 \%)$ and $\left.{ }^{54} \mathrm{Cr}^{+}(2.38 \%)\right]$. The high resolution mass spectrum (Fig. 4) shows a $\mathrm{Cr}$ isotope and a small contribution of polyatomic ions at mass $52^{+}$, the most important being $\mathrm{CaC}$. Thus, in Fig. 2B, some $\mathrm{Cr}$ emissive points are the same as $\mathrm{Ca}$ emissive points.

Ion micrographs, using the ion microprobe, were obtained from semithin sections of Cr-exposed filaments (Fig. 5). Better resolution was obtained from this apparatus allowing improved distinction of organelles of epithelial cells. The ${ }^{26} \mathrm{CN}^{-}$image (Fig. 5A) shows the precise tissue topography, with nuclei, microvilli and

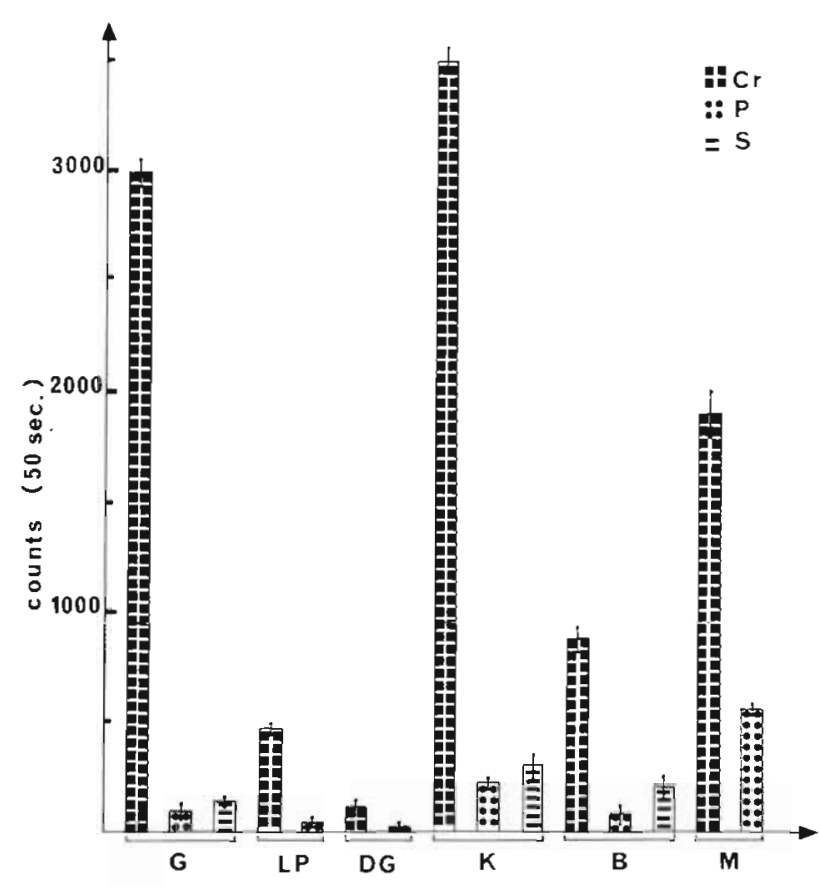

Fig. 8. Mytilus edulis. Cr-exposed mussels. Tissue distribution of chromium (Cr), phosphorus (P) and sulfur (S) obtained by X-ray microanalysis (electron microprobe). Elements were detected from lysosomes of gill (G), labial palp (LP), digestive gland (DG) and kidney (K) and from non-membrane-limited granules of byssus (B) and muscle (M). Bars represent means and standard deviation from measurements on 20 organelles from 10 individuals

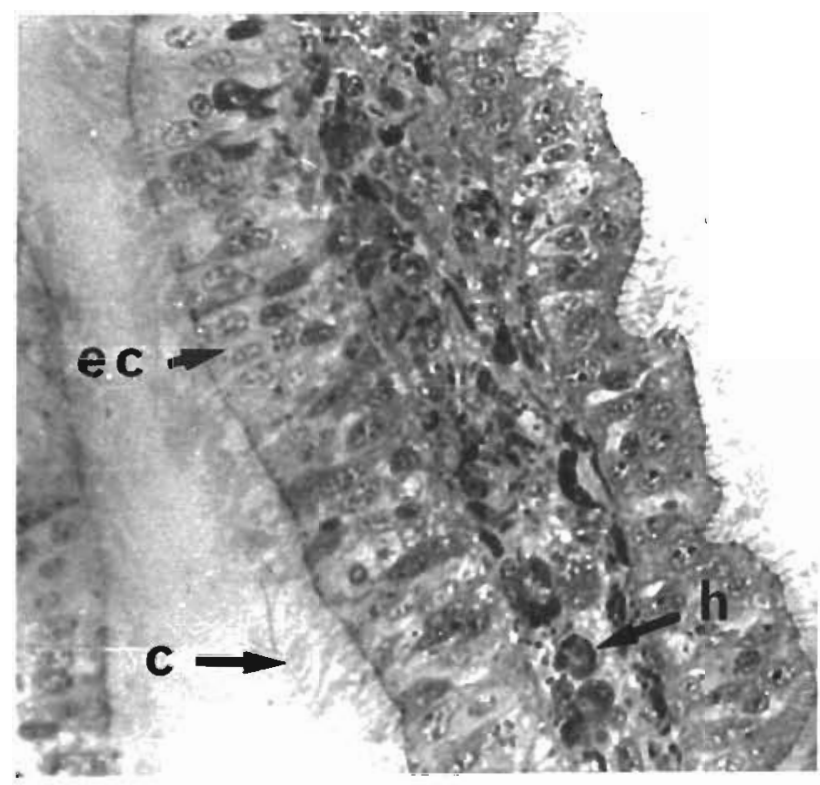

Fig. 9. Mytilus edulis, Cr-exposed labial palp. Photon micrograph of semithin section of filament showing epithelial cells (ec) with cilia (c); h: haemocyte: $\times 800$ 
cilia. The ${ }^{52} \mathrm{Cr}^{+}$image (Fig. 5B), shows $\mathrm{Cr}$ emission exclusively from small points located along the cell border.

Microanalyses performed at the ultrastructural level, using the electron microprobe, demonstrated the organelles in which $\mathrm{Cr}$ was concentrated and the chemical form in which $C r$ was stored. Figs. 6 and 7
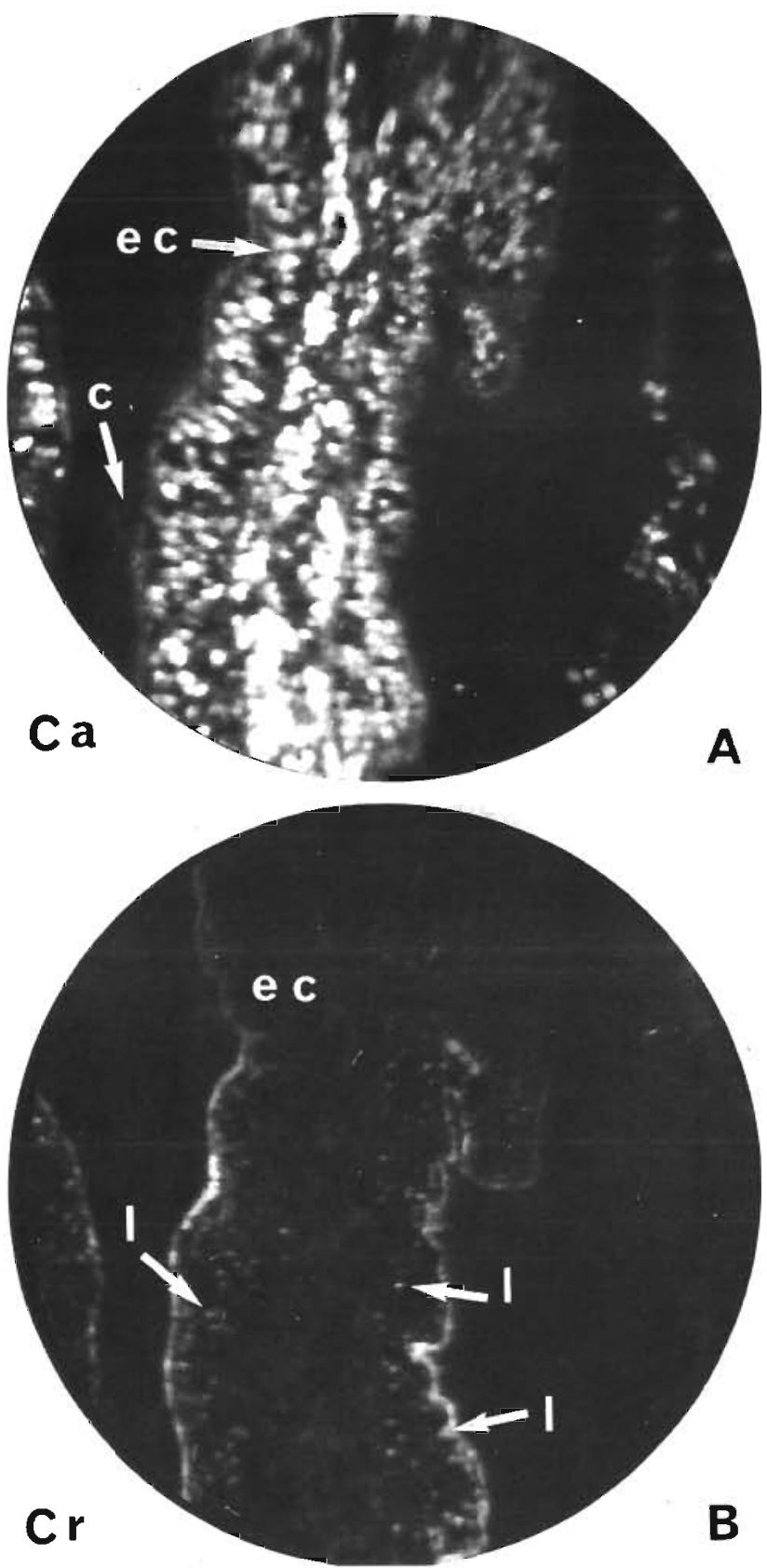

Fig. 10. Mytilus edulis. Cr-exposed labial palp. Ion microscope micrographs of semithin section of filament. (A) ${ }^{40} \mathrm{Ca}^{+}$image showing the topography of the section: epithelial cells (ec) with cilia $(\mathrm{C}) ; \times 800$. $(\mathrm{B}){ }^{52} \mathrm{Cr}^{+}$image ostained from the same area as (A) showing $\mathrm{Cr}$ emission from small points corresponding to lysosomes (l) of the epithelial cells (ec); $\times 800$ show that lysosomes contain dense granules. The X-ray emission spectra obtained from these granules indicate the presence of $\mathrm{Cr}\left(\mathrm{K}_{\alpha}\right.$ line), $\mathrm{P}\left(\mathrm{K}_{\alpha}\right.$ line) and $\mathrm{S}$ ( $\mathrm{K}_{\mathrm{n}}$ line $)$. Measurements of element concentration in the lysosomes (Fig. 8) are given by the number of counts (over $50 \mathrm{~s}$ ): $\mathrm{Cr}, 2939 \pm 114 ; \mathrm{P}, 94 \pm 32 ; \mathrm{S}, 133 \pm 26$. It appears that $\mathrm{Cr}$-high emissive points of Fig. 5 correspond to $\mathrm{Cr}$-containing lysosomes of Fig. 6 .

\section{Labial palps}

A photon micrograph (Fig. 9) of a semi-thin section of Cr-exposed labial palp filament shows tissue structure of the epithelial cells which appears unaffected by the contaminant metal. Ion microscope micrographs were obtained from Cr-treated filaments. Fig. 10A indicates the general topography of the epithelial cells. Fig. 10B, which was obtained from the same section as Fig. 10A, shows Cr emission from small points of the cytoplasm. From the high resolution mass spectrum (Fig. 11), obtained from this Cr-exposed labial palp, Cr isotope

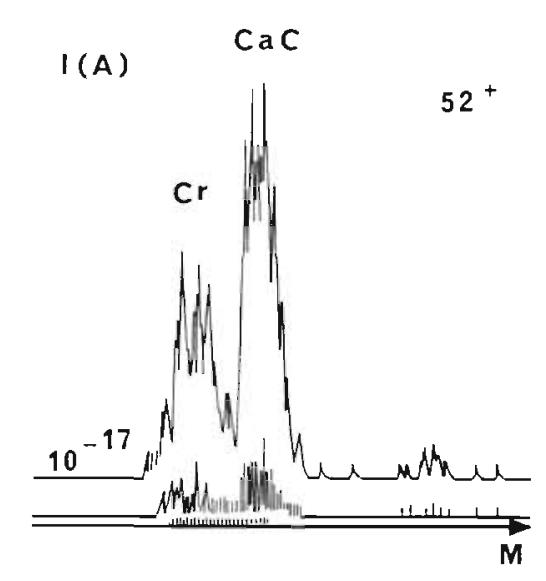

Fig. 11. Mytilus edulis. Cr-exposed labial palp. Ion microscope spectrum. High mass resolution at $52^{+}$showing the presence of $\mathrm{Cr}$ and a large contribution of polyatomic ions $\mathrm{CaC}$. I: intensity (amperes); $M$ : mass

and a large contribution of CaC polyatomic ions $(60 \%$ of the signal) appear at mass 52 .

Ion micrographs were obtained from the same $\mathrm{Cr}$ treated filaments. Better image resolution was obtained to distinguish the epithelium organelles. The ${ }^{26} \mathrm{CN}^{-}$ image (Fig. 12A), shows the cellular topography. The ${ }^{52} \mathrm{Cr}^{+}$image (Fig. 12B), shows a faint $\mathrm{Cr}$ emission exclusively from small points located along the cell border. Microanalysis was performed at the ultrastructural level, using the electron microprobe. From the electron micrographs (Figs. 13 and 14A, B), it appears that lysosomal dense microgranules contain microneedles made of $\mathrm{Cr}$ associated with $\mathrm{P}\left(\mathrm{K}_{\alpha}\right.$ line). Measurements 

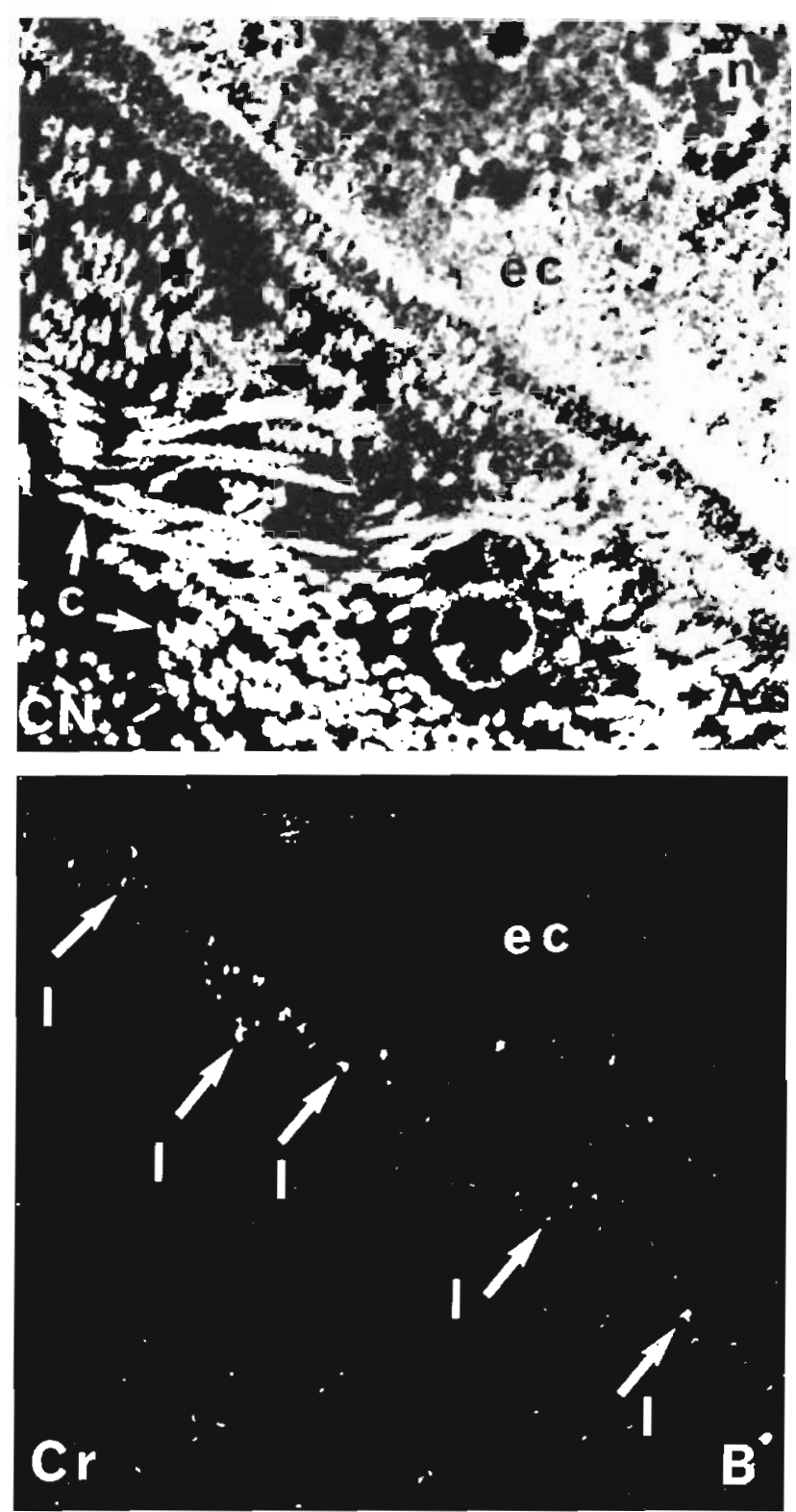

Fig. 12. Mytilus edulis. Cr-exposed labial palp. Ion microprobe micrographs of semithin section of filament. (A) $\mathrm{CN}^{-}$image showing the topography of the section: epithelial cells (ec) with cilia (c) and nuclei $(\mathrm{n})_{i} \times 2000 .(B){ }^{52} \mathrm{Cr}$ image obtained from the same area as (A) showing $\mathrm{Cr}$ emission from small points corresponding to lysosomes (1) located along the border of the epithelial cells $(\mathrm{ec}) ; \times 2000$

of element concentration in these lysosomes (Fig. 8) are given by a number of 50 s counts: $\mathrm{Cr} 478 \pm 49 ; \mathrm{P}, 39 \pm$ 20; $S$ was below the detection limit.

\section{Digestive gland}

The ion microprobe images obtained from digestive cells of the digestive diverticula (Fig. 15) allowed obser-

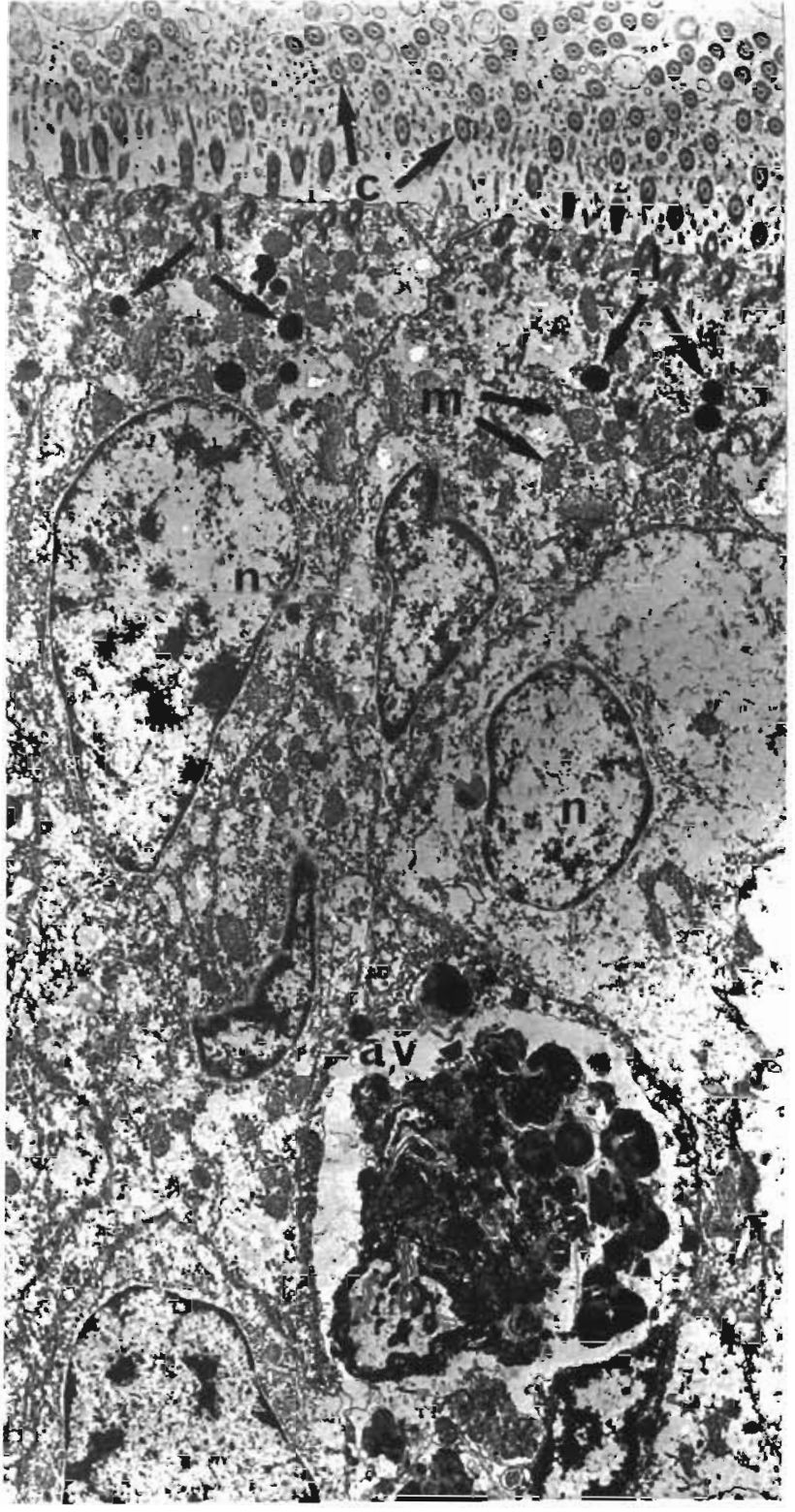

Fig. 13. Mytilus edulis. Cr-exposed labial palp. Electron micrograph showing epithelial cells with cilia (c), mitochondria (m), nuclei (n), autophagic vacuole (av) and lysosomes (l) located along the cell border and containing $\mathrm{Cr}$ and $\mathrm{P} ; \times 7800$

vations of the faint $\mathrm{Cr}$ emission from a few points of the epithelial cells. The ion spectrum (Fig. 16) confirms this observation by exhibiting a small peak of Cr associated with a higher peak corresponding to the contribution of polyatomic ions $\mathrm{CaC}$. These observations were additionally confirmed by ultrastructural observations since the emissive points of the ion image are lysosomes (Fig. 17) of the epithelial cells, containing a few granules which, analysed by X-ray spectrometry, were shown to consist of both clements: $\mathrm{Cr}, 139 \pm 31 ; \mathrm{P}, 25 \pm 12 ; \mathrm{S}$ was below the detection limit (Fig. 8) 
Fig. 14. Mytilus edulis. Crexposed labial palp. Electron micrographs of filament (non-osmicated and unstained material). (A) Epithelial cells with cilia (C), nuclei $(\mathrm{n})$ and lysosomes (l) located along the cell border and containing $\mathrm{Cr}$ and $\mathrm{P} ; x$ 7800. (B) Part of (A), seen at a higher magnification, showing 3 lysosomes (l) containing dense microgranules and microneedles of $\mathrm{Cr}$ associated with $\mathrm{P}$. Inset: $\mathrm{X}$-ray emission spectra of $\mathrm{Cr}$ and $\mathrm{P}\left(\mathrm{K}_{\mathrm{a}}\right.$ line $)$ obtained from these lysosomes: $\times 66000$
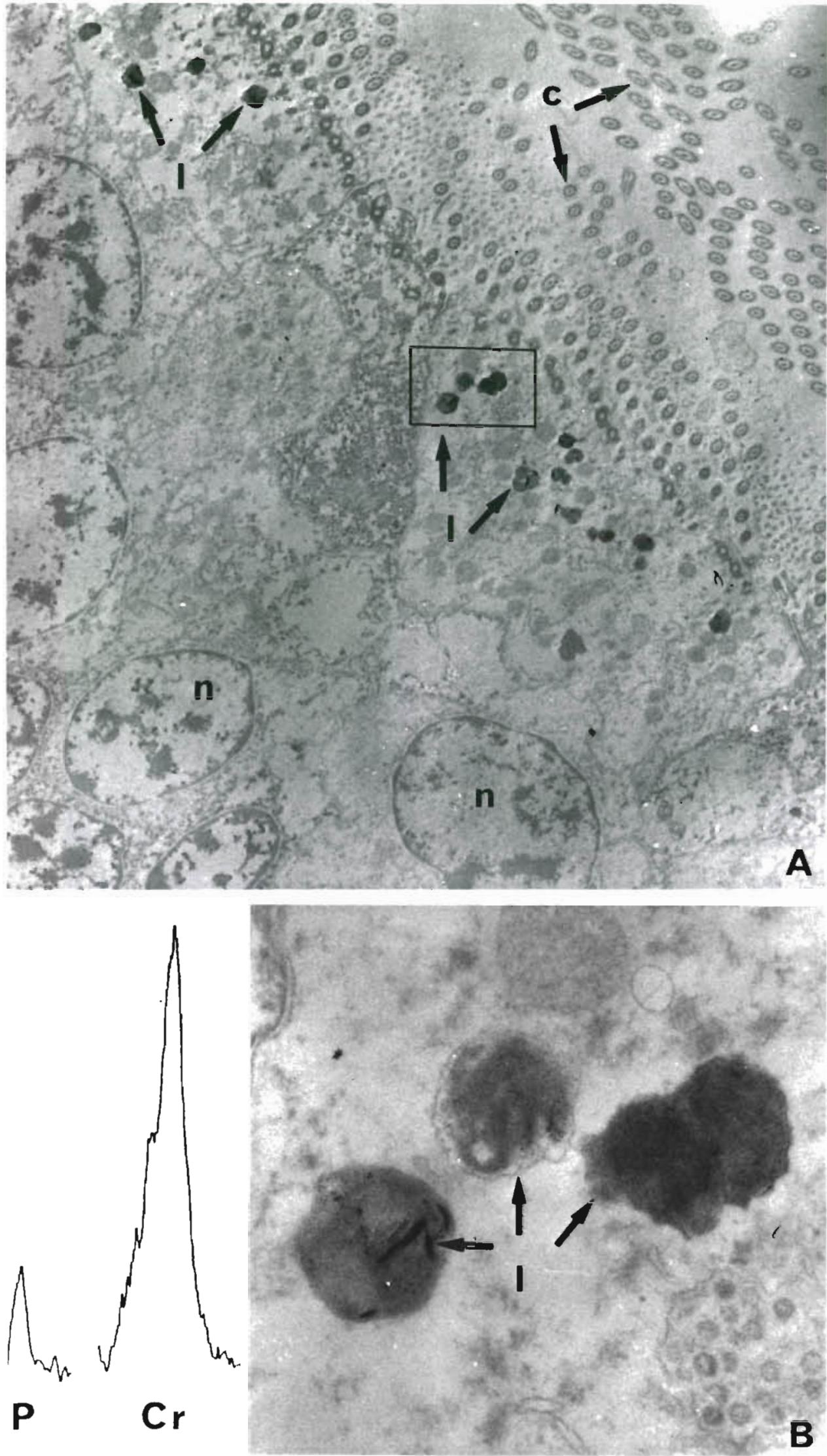

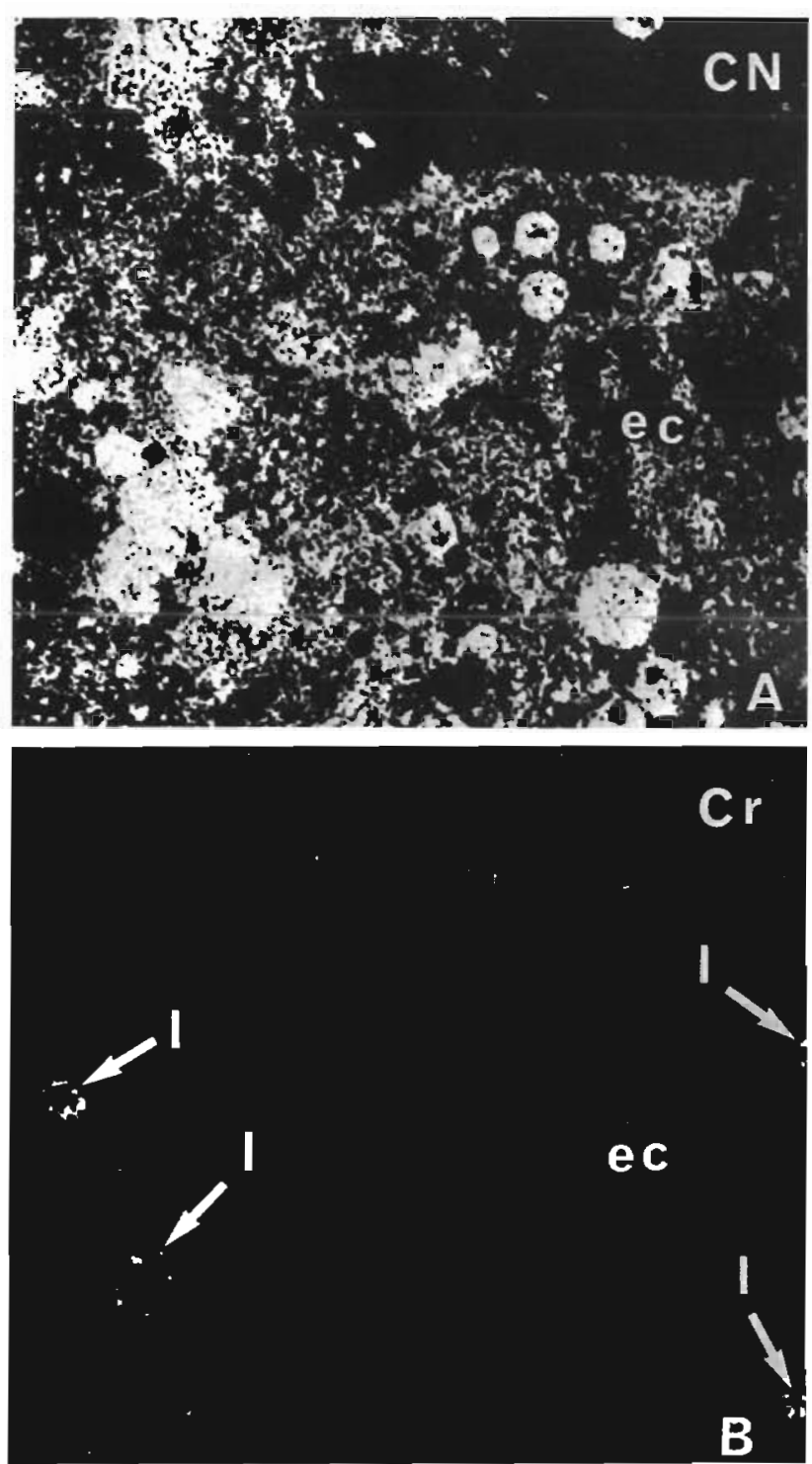

Fig. 15. Mytilus edulis. Cr-exposed digestive cells. Ion microprobe micrographs of a semithin section. (A) ${ }^{26} \mathrm{CN}^{-}$image showing the topography of the section; ec: epithelial cell ${ }_{i} \times$ 2000. (B) ${ }^{52} \mathrm{Cr}^{+}$image obtained from the same area as $(A)$, showing faint chromium emission from the scarce lysosomes

(l) of the epithelial cells (ec); $\times 2000$

\section{Kidney}

The kidney takes the form of very highly convoluted and branched diverticula surrounded by a blood sinus containing occasional amoebocytes. The ion microscope image of this organ (Fig. 18), indicates very bright $\mathrm{Cr}$ emissive points. The ion spectrum (Fig. 19) confirms this result by showing an important peak of $\mathrm{Cr}$ associated with a small one corresponding to polyatomic ions $\mathrm{CaC}$. On the electron micrograph (Fig. 20), lysosomes correspond to the emissive points of the ion image; these dense lysosomal granules can be seen together with

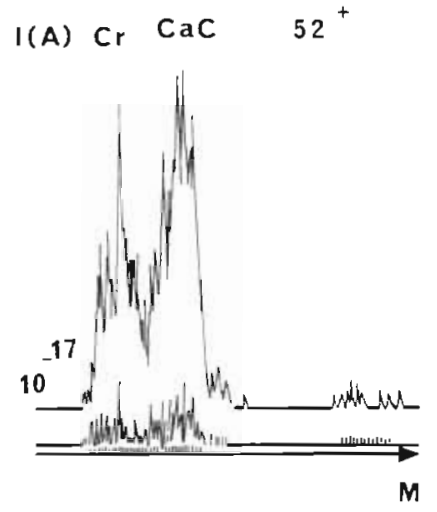

Fig. 16. Mytilus edulis. Cr-exposed digestive cells. Ion microscope spectrum. High mass resolution at $52^{+}$showing presence of $\mathrm{Cr}$ and a high contribution of polyatomic ions $\mathrm{CaC}$.

I: intensity (amperes); $\mathrm{M}$ : mass

exocytotic vesicles by which excretory products are shed from the kidney. X-ray emission spectra obtained from the exocytotic vesicles and from the lysosomes indicate the presence (Fig. 8) of Cr, $3475 \pm 134, \mathrm{P}, 215 \pm$ 39 , and $S, 307 \pm 36$. When compared to the measurements obtained from the other tissues, $\mathrm{Cr}$ levels are highest in the kidney. An electron micrograph of nonosmicated and unstained material (Fig. 21) reveals the precise location of elements within lysosomes and within the dense precipitates shed from the kidney.

\section{Byssus}

The thread 'elastic region', according to the definition given by Benedict \& Waite (1986), was investigated. It is composed of electron-dense microfilaments embedded in electron-lucent matrix forming a sinuous electron-dense wavy pattern. This region of the byssal threads was examined and analyzed by X-ray spectrometry at the ultrastructural level. Two sites of $\mathrm{Cr}$ concentration were detected. The first consisted of a thin sheath of electron-dense microneedles adsorbed onto the surface of the threads (Fig. 22). The second consisted of electron-dense microgranules incorporated into the thread. The electron micrograph (Fig. 23) shows these non-membrane-limited dense granules distributed among the matrix. Using the electron microprobe, it was possible to demonstrate that these granules contain the 3 clements $\mathrm{Cr}, 864 \pm 65 ; \mathrm{P}, 63 \pm$ 37; and S, $203 \pm 32$ (Fig. 8). The surface microneedles contained only $\mathrm{Cr}$ at a very high level: $1540 \pm 114$

\section{Muscle}

Samples of posterior adductor muscle were examined and analyzed at the ultrastructural level. Fig. 24 indi- 


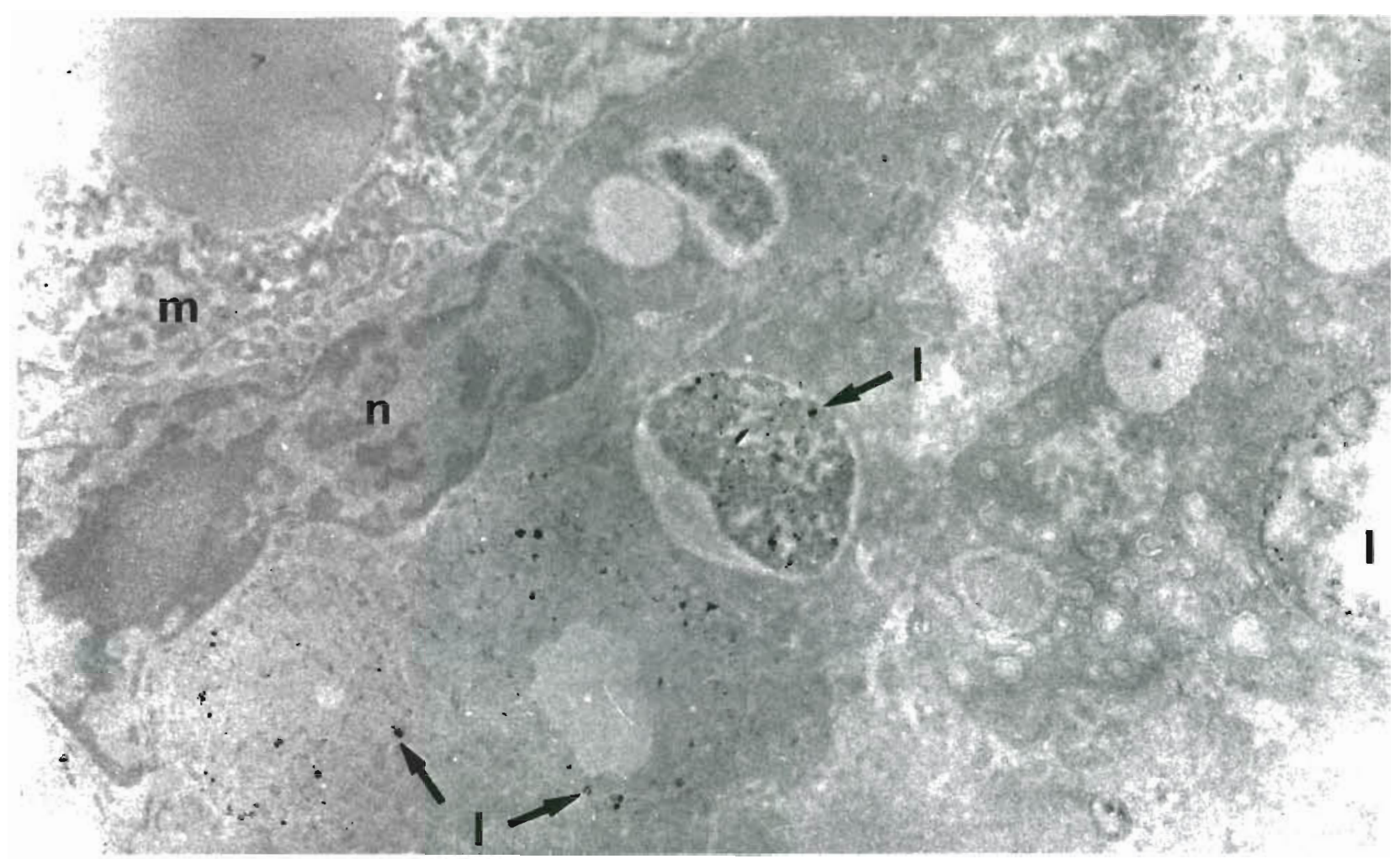

Fig. 17. Mytilus edulis. Cr-exposed digestıve cells. Electron micrograph (non-osmicated and unstaıned materıal) showng lysosomes (l) containing a few microgranules of $\mathrm{Cr}$ and P. m microvilh, $\mathrm{n}$ nucleus, $\times 20000$

cates that the muscle fibers are made up of myofibruls beside which lie nuclei, mitochondria and other cell organelles. The dense precipitates which can be identified in the cytoplasm were analyzed using the electron microprobe; they were shown to contain Cr, $1900 \pm 220$, and $P, 575 \pm 40$; $S$ was below the detection limit (Fig. 8)

\section{Gonads}

The male and female reproductive cells were investigated by microanalysis, at the structural and ultrastructural levels. No metal contamination was observed.

\section{Amoebocytes}

The amoebocytes are distributed throughout the vascular system of the mussel and because this system is semi-closed, they are also found within the tissues. These cells assume an irregular appearance with pseudopods and vacuoles in the cytoplasm. The amoebocytes are phagocytic: they play an important role in directly ingesting large particles. Fig. 25 shows a granular amoebocyte containing dense microgranules and microneedles consisting of $\mathrm{Cr}$ associated with phosphorus.

\section{DISCUSSION}

With regard to tissue and cell structure, complementary results were obtanned by microanalysis, using several different methods of secondary ion mass spectrometry Ion images were more rapidly obtained with the ion microscope: a few seconds were required, while several minutes or more were necessary to obtain one image with the ion microprobe.

Longer bombardment by the primary lons would induce tissue damage. On the other hand, higher sensitivity and resolution was obtained from the ion microprobes. At the ultrastructural level, the electron microprobe was very useful as it allowed determination of the precise location of $\mathrm{Cr}$ concentration and its chemical form. The subcellular distribution of elements could have been investigated by cell fractionation: this procedure is based on differential pelleting of a tissue homogenate, but does not give purified subcellular particles as such, but rather fractions enriched in one particular organelle such as nuclei, mitochondria or lysosomes. The enrichment is dependent on the method used and varies from one tissue to another and thus would be inadequate and not precise enough for our purpose.

The toxicity of $\mathrm{Cr}$ to fish is well documented in several species including brook trout Salvelinus fon- 


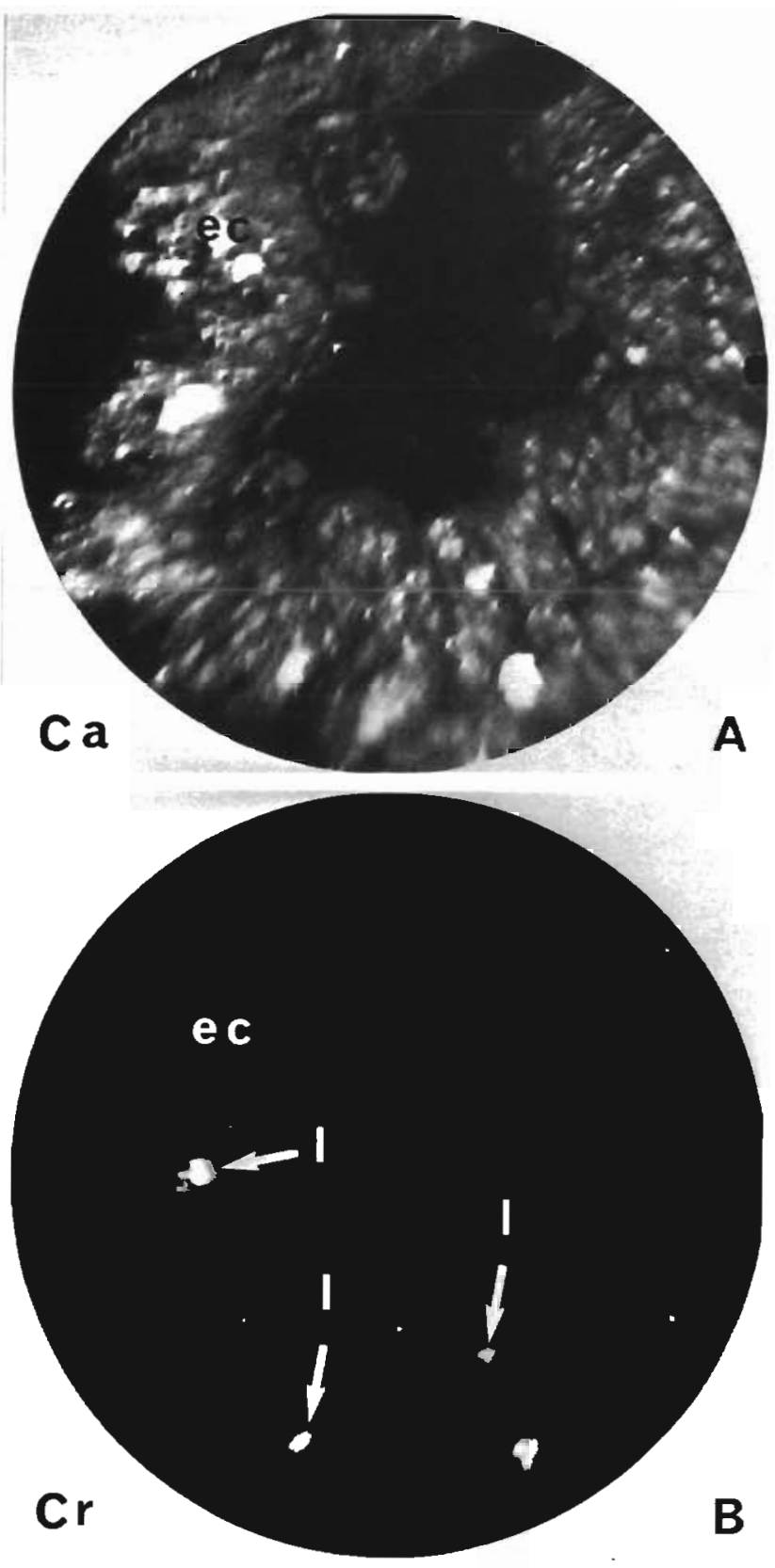

Fig. 18. Mytilus edulis. Cr-exposed kidney. Ion microscope micrographs of a semithin section. (A) ${ }^{40} \mathrm{Ca}^{*}$ image showing topography of the section; ec: epithelial cells; $\times 800$. (B) ${ }^{52} \mathrm{Cr}^{+}$ image obtained from the same area as (A) showing high $\mathrm{Cr}$ emission from lysosomes (1) of the epithelial cells (ec); $\times 800$

tinalis (Benoit 1976), rainbow trout Salmo gairdneri (Benoit 1976, Van der Putte et al. 1982, Anestis \& Neufeld 1986), fathead minnow Pimephalus promelas (Pickering 1980) and freshwater murrel Channa punctatus (Sastry \& Sunitatyagi 1982). In comparison, little information is available on $\mathrm{Cr}$ toxicity to molluscs. Available information generally concerns $\mathrm{Cr}$ concentration of soft parts or the shell, 0.5 to $1.6 \mu \mathrm{g} \mathrm{Cr} \mathrm{g}^{-1} \mathrm{dry}$

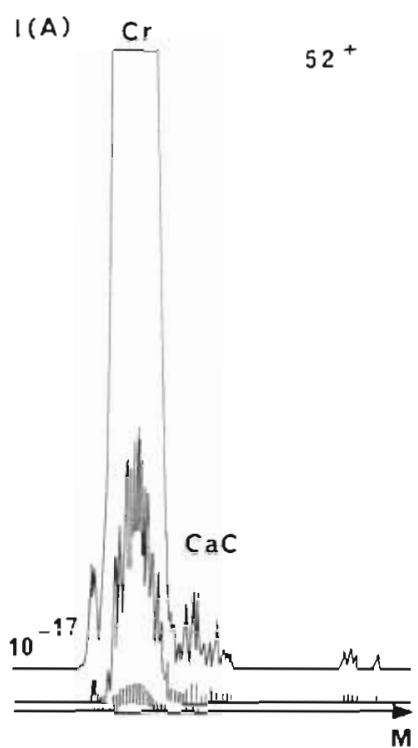

Fig. 19. Mytilus edulis. Cr-exposed kidney. Ion microscope spectrum. High mass resolution at $52^{+}$showing abundance of $\mathrm{Cr}$ and very faint contribution of polyatomic ions $\mathrm{CaC}$. I: intensity (amperes); $M$ : mass

matter for soft parts (Fukai \& Broquet 1965). More precise data were obtained for Pinna nobilis, in $\mathrm{mg} \mathrm{Cr}$ $\mathrm{kg}^{-1}$ dry weight: byssus, 32; mantle and gills, 16; muscle, 3.9; hepatopancreas, 150 (Papadopoulou 1973). The following data were obtained for Mytilus edulis, in $\mathrm{mg} \mathrm{Cr} \mathrm{kg}{ }^{-1}$ fresh weight: digestive gland, 7.4; muscle, 11 (Young \& McDermott 1975). These results are in agreement with ours in demonstrating a higher $\mathrm{Cr}$ concentration in muscle than in digestive gland. $\mathrm{Cr}$ uptake and loss by the bivalves Crassostrea virginica and $M$. edulis were studied to determine their potential as an indicator of $\mathrm{Cr}$ pollution (Zaroogian \& Johnson 1983); $\mathrm{Cr}$ concentration in oysters continued to increase during spawning, whereas it decreased in mussel: this is in agreement with our data showing no Cr concentration in the reproductive cells. Compared to oysters, mussels appear to accumulate more Cr since they have higher tissue concentrations.

Several works report marked cytopathological changes induced by $\mathrm{Cr}$ in the gills of aquatic species. In the freshwater fish Barbus conchonius, Cr-exposed gills showed eclema, collapse of pillar cells and desquamation of the respiratory epithelium, with consequent reduction of $\mathrm{O}_{2}$ uptake by the gill lamellae (Gill \& Pant 1987). Extensive alteration of the normal architecture of the lamellae was evident, with severe epithelial hyperplasia in the rainbow trout Salmo gairdneri (Van der Putte et al. 1981). In the goldfish Carassius auratus accumulation of $\mathrm{Cr}$ by gills was not related to dose or temperature (Riva et al. 1981). Histopathological and ultrastructural changes in gill of grass shrimp Palaemonetes pugio following exposure to $\mathrm{Cr}$ were described 


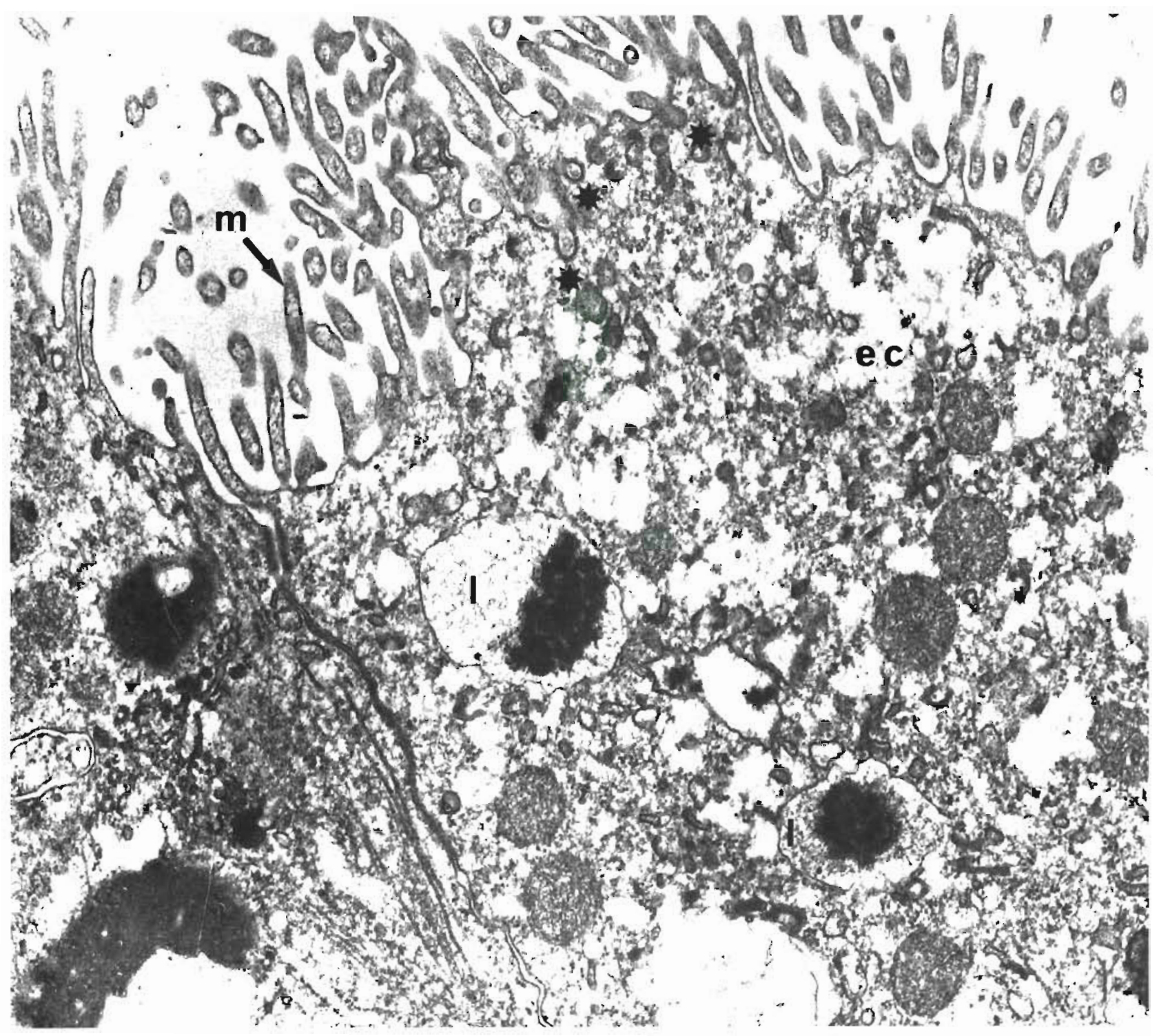

Fig. 20. Mytilus edulis. Cr-exposed kidney Electron micrograph showing epithelıal cells (ec) with microvillı (m) and lysosomes (l) containing $\mathrm{Cr}, \mathrm{P}$ and $\mathrm{S}$. Note presence of exocytosis vesıcles (stars) by which metals are shed from the kidney; $\times 26000$

as follows (Doughtie \& Rao 1984): irregular profiles of gill lamellae indicating pronounced cellular distension, cellular disorganization, increased number of lysosomes and distended cisternae of rough endoplasmic reticulum. In the shrimp, major degenerative changes due to $\mathrm{Cr}$ contamination were restricted to the gills, with overall decrease in epithelial cytoplasmic density and a loss of euchromatin density Thus, it appears that the cytopathological changes we were able to observe in the mussel may be compared to the ones observed in fish and shrimps. The gill seems to be, in all these organisms, the predominant site of $\mathrm{Cr}$ toxic action. Gill lesions were also observed in samples of Mytilus edulis collected from a harbour polluted by discharges of an iron and steel factory (probably con- tainıng $\mathrm{Cr}$ ) by Sunıla (1987) In these specimens part of the interfilamentar ciliary junctions were replaced by metaplastic cellular connections and chronic inflammatory reaction was observed. These gill lesions assoclated with heavy metal stress affect gas exchange and food transport.

The digestive gland is commonly known to be the main organ of metal concentration in many invertebrates. Using microanalytical techmiques we investıgated several organs (digestive gland, kidney, gill, labial palp) of Mytilus edulis. We were able to demonstrate that the digestive gland of mussel is the target organ for the storage of many elements: lithium, the lightest metal (Chassard-Bouchaud et al. 1984), aluminium (Chassard-Bouchaud \& Galle 1986), heavy 


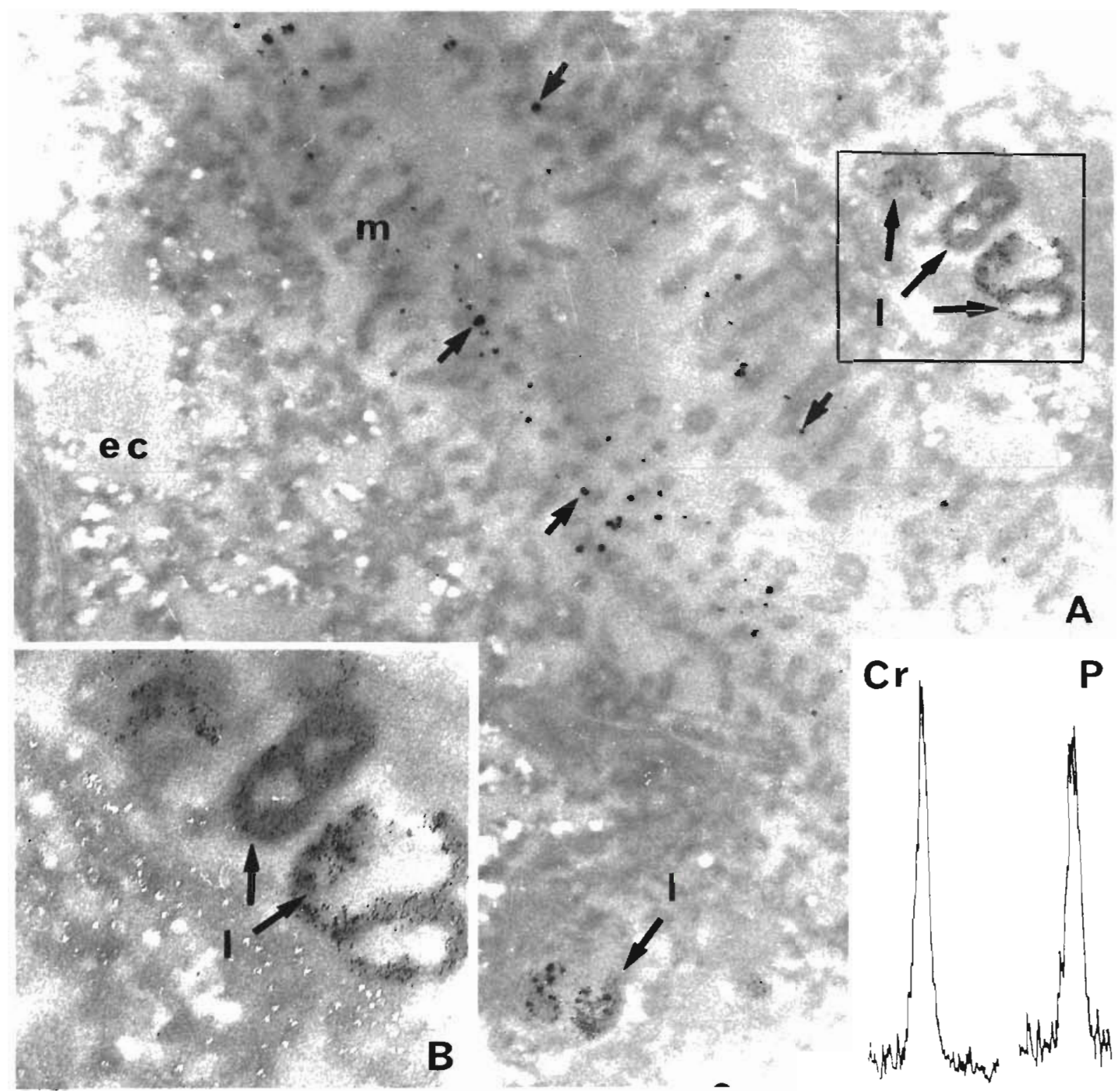

Fig. 21 Mytılus edulis Cr-exposed kıdney Electron micrographs (non-osmicated and unstained material). (A) Epithelial cells (ec) with microvillı $(\mathrm{m})$ and lysosomes (l) located along the cell border, containıng $\mathrm{Cr}$, P and S Note dense precipitates of metal shed from the kidney (arrows) Inset $X$-ray emission spectra of $\mathrm{Cr}$ and $\mathrm{P}\left(\mathrm{K}_{\mathrm{a}}\right.$ line) obtaned from these lysosomes; $\times 32$ 000. (B) Part of (A), seen at a higher magnification, showing lysosomes (l) containing dense microgranules of $\mathrm{Cr}, \mathrm{P}$ and $\mathrm{S} ; \times 66000$

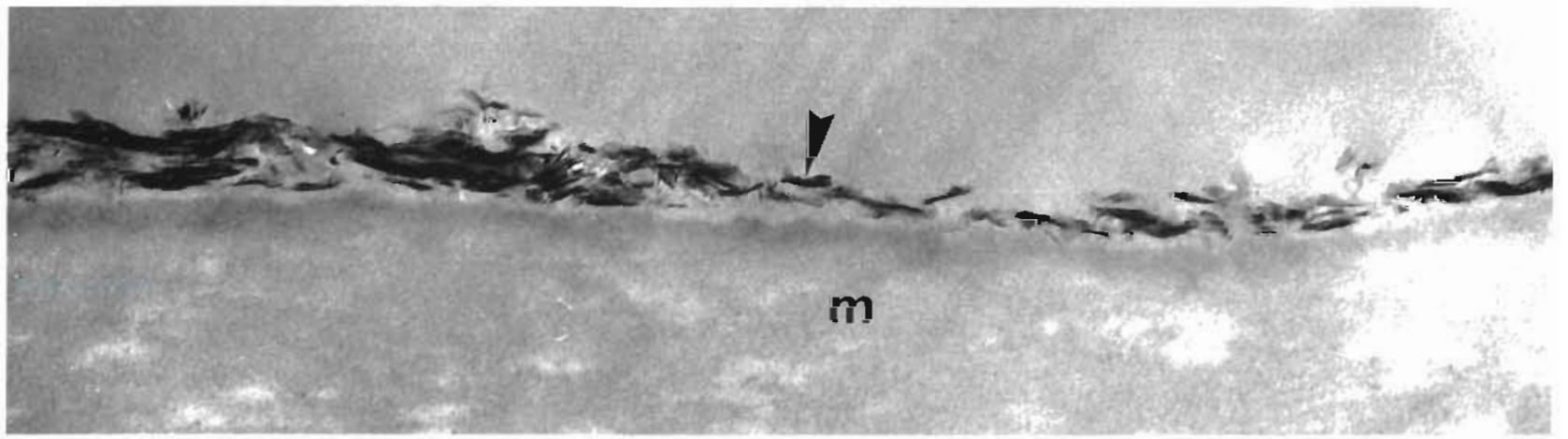

Fig. 22 Mythlus eduhs. Cr-exposed byssal thread Electron micrograph showing a sheath of electron-dense Cr microneedles (arrow) adsorbed onto the surface of the matrix (m) Non-osmicated and unstained material $\times 40000$ 


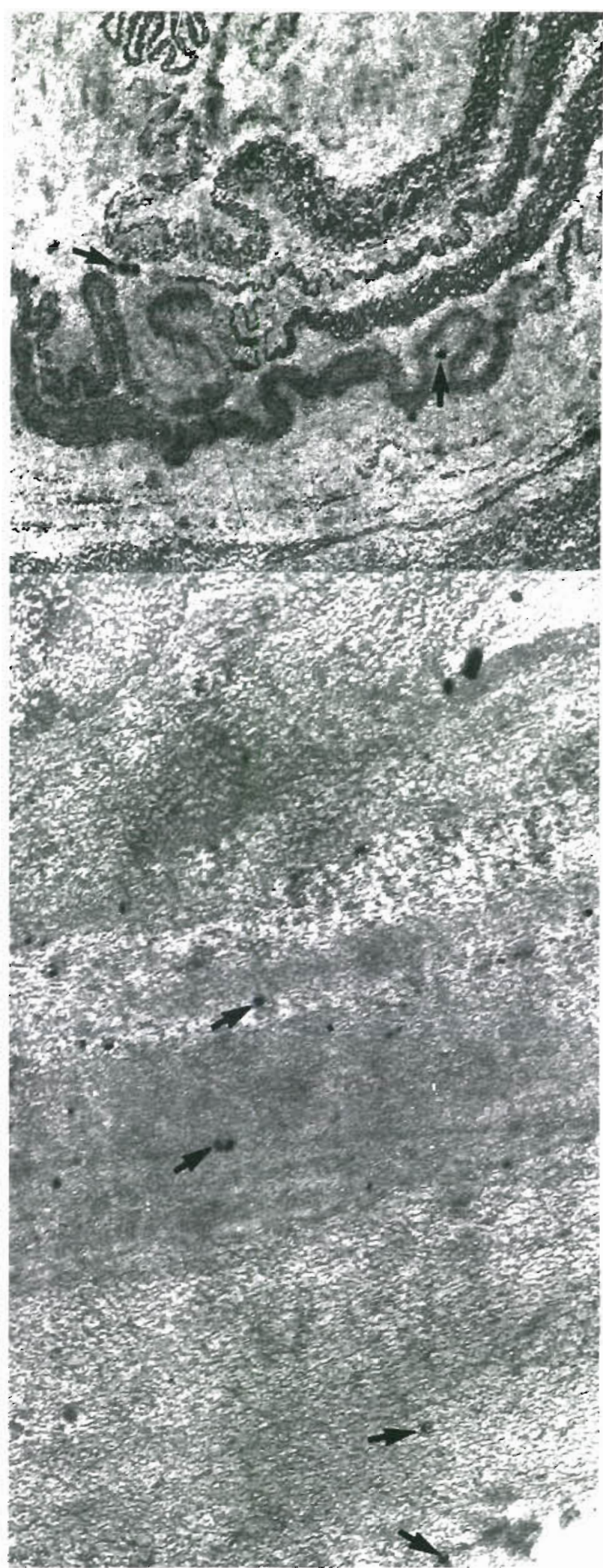

Fig. 23 Mytilus edulls $\mathrm{Cr}$-exposed byssal thread. Electron micrograph showing dense granules (arrows) of $\mathrm{Cr}, \mathrm{P}$ and $\mathrm{S}$; $\times 16400$ metals such as silver and lead (Chassard-Bouchaud et al. 1985), lanthanids (Chassard-Bouchaud \& Hallegot 1984) and radionuclides such as uranium (ChassardBouchaud \& Escaig 1984) and plutonium (Calmet et al. 1987). It appears from our present data that $\mathrm{Cr}$ behaves toxicologically in a different manner from most other metals in $M$. edulis since the digestive gland is the tissue which exhibits one of the lowest Cr levels.

Our results reveal that the kidney of Mytilus edulis had the highest mean $\mathrm{Cr}$ concentration and may be considered the prime determinant site of $\mathrm{Cr}$ concentration. In this specific case, it seems that the kidneys, saturated with $\mathrm{Cr}$, were unable to maintain their excretory function and were adopting a storage function. Our results are similar to those of George \& Pirie (1980) who concluded that the kidney forms the major storage organ for zinc.

Cr has been detected in muscle tissue of many species of teleost fish (Plaskett \& Potter 1979, Elwood et ai. 1980) and it was suggested (Buhler et al. 1977) that fish have 2 major $\mathrm{Cr}$ compartments, a rapid turnover pool consisting mainly of soluble Cr (VI) in physiological fluids and a slow turnover pool consisting of Cr (III) bound to tissue proteins. In crustaceans such as the crayfish Procambarus clarkii, highest $\mathrm{Cr}$ accumulation occurred in the gills, whereas the lowest accumulation occurred in muscle (Hernandez et al. 1986). In the crab Xantho hydrophilus, similar results were obtained by Peternac \& Legovic (1986): Cr concentration was highest in the gills with a concentration factor (CF) of 400 to 798, followed by hepatopancreas (CF 196 to 392), skeleton (CF 80 to 160), muscle (CF 52 to 104) and hemolymph (CF 14 to 28)

Our present data on $\mathrm{Cr}$ concentration in the muscle tissue of the mussel are consistent with those obtained on fish and crustaceans. It should be noted that, in our previous investigations on metabolism of other metals, highest lithium levels were detected from fish muscle (Chassard-Bouchaud et al. 1984).

The structural tensile elements of byssal threads consist of collagen and of a non-collagenous protein (Pujol 1966, Smeathers \& Vincent 1979, Price 1983), and of catechol oxidase which may be responsible for the quinone-tanning of the byssus (Waite 1985). Although copper is usually the prosthetic metal associated with phenol oxidase, several other metals were also detected at significant levels in byssus of Mytilus sp. by Coombs \& Keller (1981). These authors were able to detect, in the byssal threads of mussels collected from a variety of environments, significant concentrations of zinc, iron and copper, high concentrations of calcium, magnesium, sodium and potassium, together with a wide variety of other elements present in trace amounts such as silver, gold and uranium. These elements were shown to reflect the geochemical nature of the environ- 

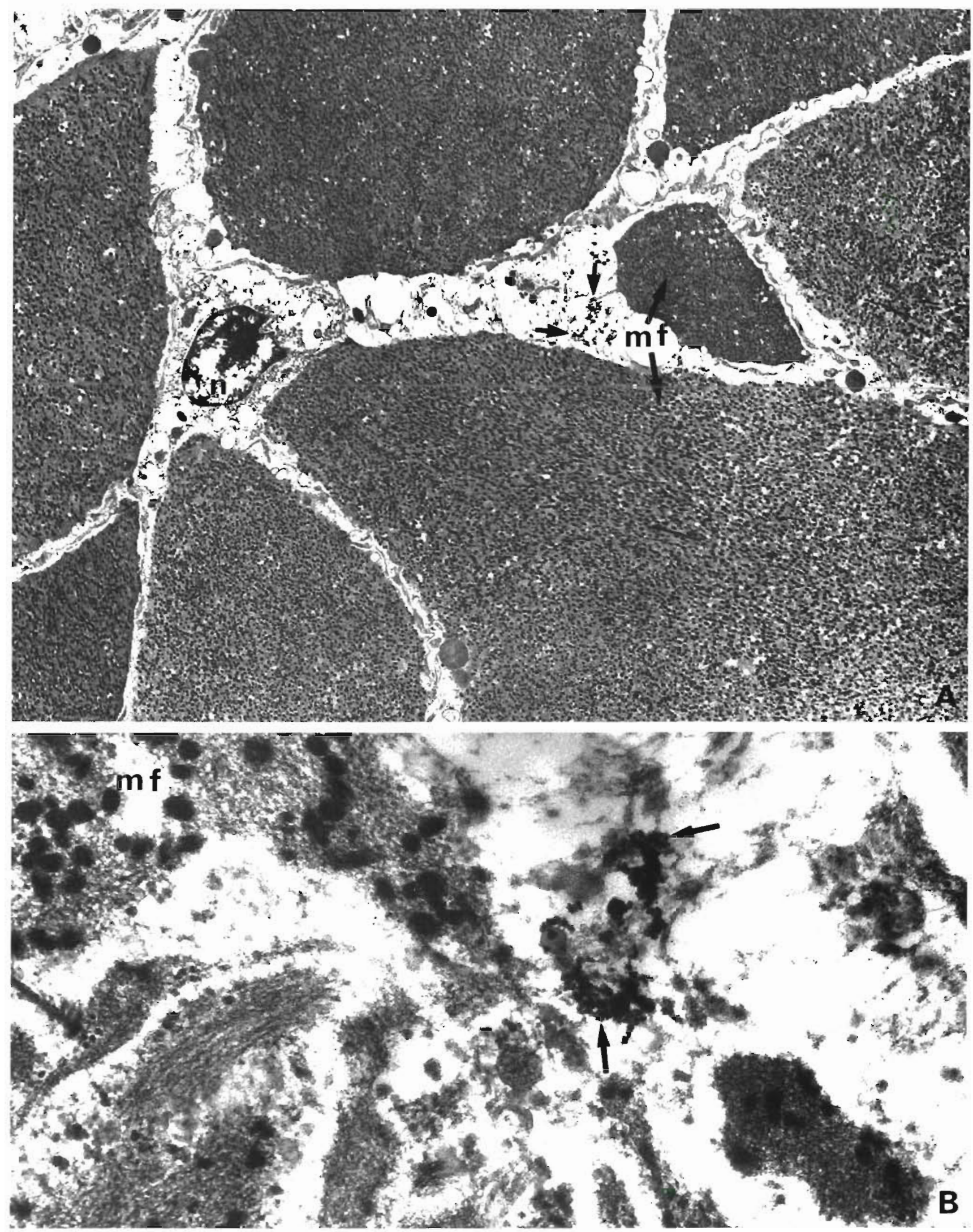

Fig. 24. Mytilus edulis. Cr-exposed muscle. Electron micrographs of cross-section of adductor muscle fiber. (A) Muscle fiber is made up of myofibrils (mf) beside which lie nucleus ( $\mathrm{n}$ ) and $\mathrm{Cr}$ and $\mathrm{P}$ microprecipitates (arrows); $\times 7800$. (B) $\mathrm{Cr}$ and $\mathrm{P}$ microprecipitates (arrows) seen at a higher magnification; mf: myofibrils; $\times 66000$ 


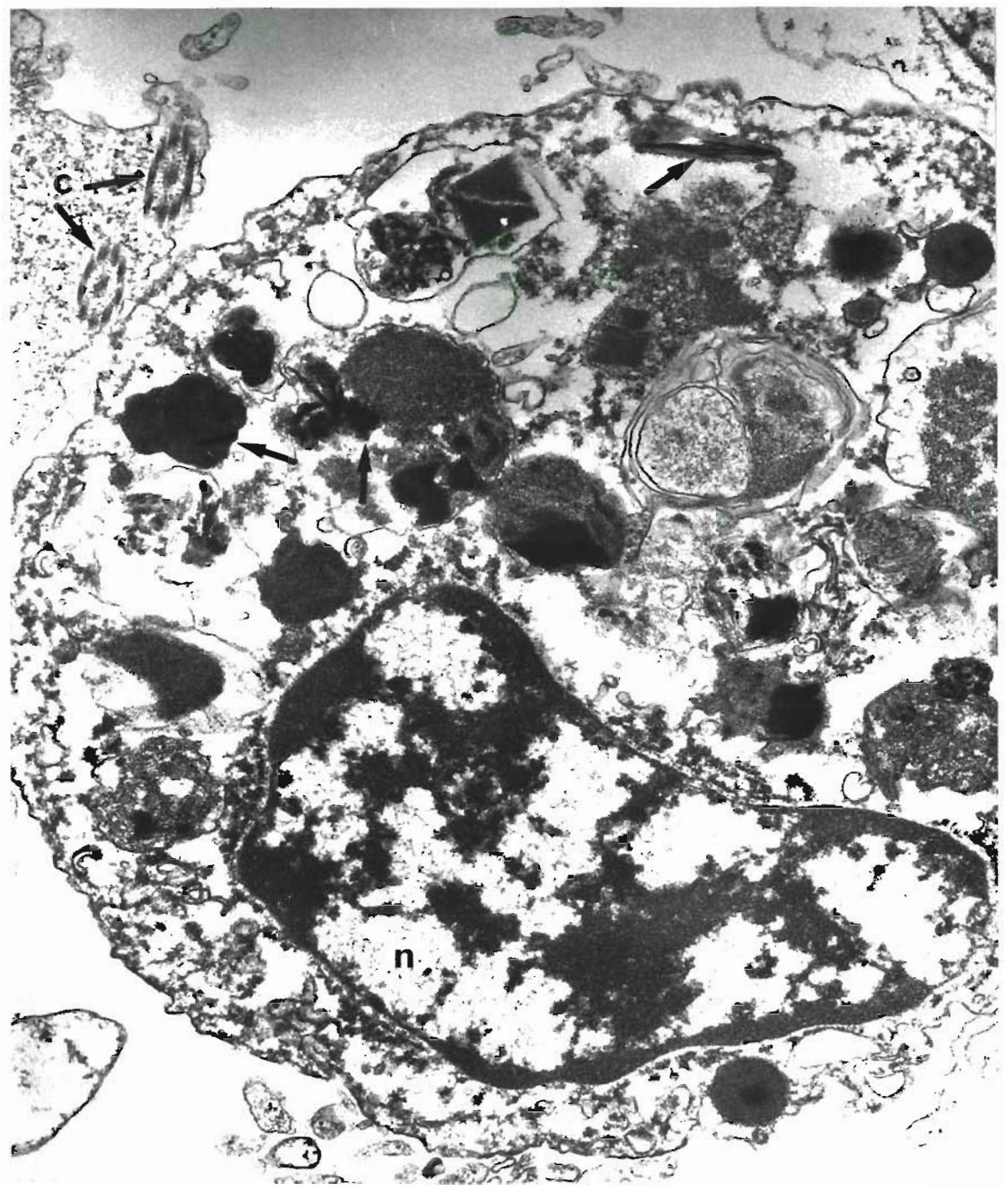

Fig. 25. Mytilus edulis. Cr-exposed macrophage amoebocyte. Electron micrograph showing heterogenous content of the cell, among which $\mathrm{Cr}$ microgranules and microneedles are visible (arrows); c: cilia; n: nucleus; $\times 32000$

ment. For the radionuclide the concentration in the byssal threads was 10 -fold higher than in the rest of the soft tissues. The same authors question whether the metals would be either adsorbed or complexed directly from the surrounding waters onto the threads, or incorporated within the tissues. Our data, obtained by microanalytical imaging techniques, clearly support the existence of both mechanisms for $\mathrm{Cr}$ concentration in the byssal threads of the mussel. An iron excretion role for the byssus has been suggested (George et al. 1976), involving transfer from the other tissues to the byssus via the haemolymph. In experiments on factors influencing the flux of arsenic through Mytilus galloprovincialis, Unnlü \& Fowler (1979) found the highest concentration of ${ }^{74} \mathrm{As}$ in the byssus. We can conclude with these authors that the byssal threads may consti- 
tute a significant pathway for the elimination of metals. This process would provide a simple and convenient method for monitoring long-term environmental changes in metal toxicants.

Granular amoebocytes of Mytilus edulis were shown to contain $\mathrm{Cr}$ microparticles. In bivalves, these cells can perform both intra and extracellular digestion of foreign particles. They migrate to the digestive gland, kidney and other epithelial linings where they are discharged to the exterior. These cells are involved in the phagocytic clearance of pollutants (Read \& Read 1972) as they are enzymatically equipped with lysosomal phosphatase. Our results are in agreement with this concept, according to which granular amoebocytes perform detoxication of metals, such as zinc, iü the oyster Ostrea edulis (George et al. 1078) and in the mussel Mytilus edulis (George \& Pirie 1980).

At the subcellular level, we were able to investigate nuclei, mitochondria and lysosomes of all the organs and tissues in order to locate more precisely the sites of $\mathrm{Cr}$ concentration as well as determine the insoluble chemical form in which it was precipitated. The lysosome appears to be the target organelle of $\mathrm{Cr}$ concentration, as no metal was detected from other organelles. These data are in agreement with our previous results showing that lysosomes of Mytilus edulis are the target sites of several metals such as aluminium (ChassardBouchaud \& Galle 1986), lanthanum. (ChassardBouchaud \& Hallegot 1984) and uranium (ChassardBouchaud 1983, Chassard-Bouchaud \& Escaig 1984). We agree with George et al. (1982) who proposed that Mytilus may be a useful model system for the study of intralysosomal metal accumulation.

In the lysosomes, $\mathrm{Cr}$ was concentrated in an insoluble from and associated with phosphorus and sulfur. Chromium phosphate was the result of an enzymatic reaction of acid phosphatase activity, as previously demonstrated by a method based on its microanalytical visualisation (Berry et al. 1982). The presence of sulfur, associated with $\mathrm{Cr}$ in the lysosome, may be explained by the possible existence of thionein-like protein. Metallothioneins in mussels were first described by Nöel-Lambot (1976). Since then numerous papers describing different metallothioneins in mussels have been published (George \& Pirie 1979. George et al. 1979, Viarengo et al. 1986). By sequestering $\mathrm{Cr}$, lysosomes play a defensive role by preventing the diffusion of the toxic metal throughout the cell.

In conclusion, $\mathrm{Cr}$ uptake by Mytilus edulis occurs via the gills where high levels of metal were detected, inducing major cellular degenerative changes there. Contaminated water is then conveyed towards the labial palps before entering the digestive system. The main storage tissue appears to be muscle, while the digestive gland plays a very minor role in the metal concentration. Byssal threads are involved in Cr storage and excretion which however is chiefly performed by the kidney which exhibited the highest Cr levels. Granular amoebocytes are involved in Cr uptake, storage and excretion. The target organelle of $\mathrm{Cr}$ concentration was the lysosome where the metal was associated with phosphorus and sulfur, in an insoluble form

From our data, it appears that Mytilus edulis may be considered as a biological indicator of $\mathrm{Cr}$ pollution. Investigations of byssal threads, using several microanalytical techniques, could provide, easily and rapidly, useful information on tissue levels relative to environmental contamination.

Acknowledgements. This work was financially supported by the Fond and Agriculture Organization of the United Nations: MED POL II Programme (contract FRA 24 G), by the National Science Foundation of the United States (grant BBS-8610518) and by INSERM France (S.C.27). We thank F. Escaig, P. Boumati, F. Kleinbauer and J. Brissard for their technical assistance, and $\mathrm{G}$. Plessard for drafting the drawings. Electron microscopy was performed in Laboratoire de Microscopie Electronique appliquée à la Biologie, 105 Bd. Raspail, F-75006 Paris, France.

\section{LITERATURE CITED}

Anestis, I., Neufeld, R. J. (1986). Avoidance preference reactions of rainbow trout (Salmo gairdneri) after prolonged exposure to chromium VI. Wat. Res. 20: 1233-1241

Benedict, C. V., Waite, J. H. (1986). Composition and ultrastructure of the byssus of Mytilus edulis. J. Gorph. 189: 261-270

Benoit, D. A. (1976). Toxic effects of hexavalent chromium on brook trout (Salvelinus fontinalis) and rainbow trout (Salmo gairdneri). Wat. Res. 10:497-500

Berry, J. P., Hourdry, J., Sternberg, M., Galle, P. (1982) Aluminium phosphate visualisation of acid phosphatase activity: a biochemical and X-ray microanalysis study. $J$. Histochem. Cytochem. 30: 86-90

Bryan, G. W. (1980). Recent trends in research on heavy metal contamination in the sea. Helgoländer Meeresunters. 33: $6-25$

Buhler, D. R., Stokes, R. M., Cadwell, R. S. (1977). Tissue accumulation and enzymatic effects of hexavalent chromium in rainbow trout (Salmo gairdneri). J. Fish. Res. Bd Can. 34: 9-18

Calmet, D., Charmasson, S., Willemot, J. M., Verry, M., Chassard-Bouchaud, C., Inglebert, R. L., Outrequin, M., Galle, P. (1987). Suivi des niveaux de plutonium 239-240 dans des moules Mytilus sp. prélevées sur le littoral français (1983-1984): études radiochimique et microanclytique. C.r. hebd. Séanc. Acad. Sci, Paris 304 (Sér. III) 9: 199-206

Cavellier, J. F., Escaig, F., Boumati, P., Gaume, P., Hallegot, P. (1988). Numerisation and digital processing of images in secondary ion microscopy. In: Benninghoven, A., Huber, A. M. Werner, H. W. (eds) Secondary Ion Mass Spectrometry SIMS VI. John Wiley and Sons, New York, p. 385-388

Chassard-Bouchaud, C. (1983). Röle des lysosomes et des spherocristaux dans le phénomene de concentration de l'uranium chez la moule Mytilus edulis. Microanalyse par 
spectrographie des rayons X. C.r. hebd. Seanc. Acad. Sci, Paris 296 (Sér. III): 581-586

Chassard-Bouchaud, C. (1987). Ion microscopes and microprobes in murine pollution research. Analytica chim. Acta 195: 307.315

Chassard-Bouchaud, C. (1988). Current trends and applications of second diry ion microscopy in medicine and biology: a review. In: Benninghoven, A., Huber, A. M., Wemer, H.W. (eds.) Secondary Ion Mass Spectrometry SIvIS VI. John Wiley and Sons, New York, p. 85j-863

Chassard-Bouchaud, C, Escaig, F. (1984). Uptake, storage and excretion of uranıum by Mytilus edulis. A structural ultrastructural and microanalytical study by secondary ion mass and X-ray spectrometry. J. Phys., Paris 45: 545-5.48

Chassard-Bouchaud, C., Galle, P. (1986). Bioaccumulation. d'aluminium par les organusmes marins. Mise en évidence par microscopie corpusculaire analytique. C.r hebd. Séanc. Acad. Sci., Paris 302 (Sér III) 2: 55-61

Chassard-Bouchaud, C., Galle, P. (1988). Sites cellulaires de concentration du chrome chez la moule Mytilus edulis: données préliminaires. C.r. hebd. Séanc. Acad. Sci., Paris 306 (Sér. III) : 467-473

Chassard-Bouchaud, C., Galle, P., Escaig, F. (1985). Mise en évidence d'une contamination par l'argent et le plomb de l'huitre Crassostrea gigas et de la moule Mytilus edulis dans les eaux côtières françaises. Etude microanalytique par émission ionique secondaire. C.r. hebd. Séanc. Acad. Sci., Paris 300 (Sér III) 1. 3-8

Chassard-Bouchaud, C., Galle, P., Escaig, F., Miyawaki, M. (1984). Bioaccumulation de lithium par les organismes marins des zones côtières européenes, américaines et asiatiques: étude microanalytique par emission ionique secondaire. C.r. hebd. Séanc. Sci., Paris: 299 (Sér Irl) 18 $719-724$

Chassard-Bouchaud, C., Hallegot, P. (1984). Bioaccumulation de lanthane par des moules Mytilus edulis récoltées sur les côtes françaises. Microanalyse par spectrographie des rayons $X$ et par émission ionique secondaire. C.r hebd. Séanc. Acad. Sci. Paris 298 (Sér. III) 20: 567-572

Coombs, T L., Keller, P. J. (1981). Mytilus byssal threads as an environmental marker for metals. Aquat. Toxic 1:291-300

Doughtie, D. G., Rao, R. K. (1984). Histopathological and ultrastructural changes in the antennal gland, midgut, hepatopancreas and gill of grass shrimp following exposure to hexavalent chromium. J. Invertebr Pathol. 43 89-108

Elwood, J. W., Beauchamp, J. J., Allen, C. P. (1980). Chromium levels in fish from a lake chronically contaminated with chromates from cooling towers. Int. J. envirl Stud. 14: 289-298

Fukai, R., Broquet, D. (1965). Distribution of chromum in marine organisms. Bull Inst. océanogr Monaco 65 (1336) $3-19$

George, S. G., Carpene, E., Coombs, T. L., Overnell, J., Youngson, A. (1979). Characterisation of cadmium-binding proteins from mussels, Mytilus edulis (L.), exposed to cadmium. Biochim. Biophys. Acta 580: 225-233

George, S. G., Coombs, T L., Pirie, B. J. S. (1982). Characterisation of metal-containing granules from the kidney of the common mussel Mytilus edulis. Biochim. Biophys. Acta 716: 61-71

George, S. G., Pirie, B. J. S. (1979). The occurrence of cadmium in sub-cellular particles in the kidney of the marine mussel, Mytilus edulis, exposed to cadmium. The use of electron microprobe analysis. Biochim. Biophys. Acta 580: $234-244$

George, S. G., Pirie, B. J. S. (1980). Metabolism of zinc in the mussel Mytilus edulis (L.): a combıned uitrastructural and biochemical study. J. mar biol. Ass. U. K. 60: 575-590

George, S. G., Pirie, B. J. S., Cheyne, A. R., Coombs, T L., Grant, P. T. (1978). Detoxication of metals by marine bivalves: an ultrastructural study of the compartmentation of copper and zinc in the oyster Ostrea edulis. Mar. Biol. 45: $147-156$

George, S. G., Pirie, B. J. S. Coombs, T L. (1976). The kinetics of accumulation and excretion of ferric hydroxide in Mytilus edulis (L.) and its distribution in the tissues. J. exp. mar. Biol. Ecol. 23: 71-84

Gill, T. S., Pant, J. C. (1987). Hematological and pathological effects of chromium toxicosis in the freshwater fish Barbus conchonius Ham. Wat. Air Soil Poll. 35: 241-250

Günter, T., Ruhe, B., Schmalbeck, J., Tehrani, N. (1974). Biochemistry of trace elements $\mathrm{Zn}, \mathrm{Cu}, \mathrm{Cr}$ and $\mathrm{Co}$ : distribution, binding and regulation by adrenal hormones. $Z$. klin. Chem. klin. Biochem. 12: 327-335

Hernandez, F., Diaz, J., Medina, J., Delramo, J., Pastor, A. (1986). Deternination of chromium treated crayfish Procambarus clarkii by electro-thermal AAS: study of $\mathrm{Cr}$ accumulation in different tissues. Bull. envir Contam. Toxic. 36: 851-857

Karbe, L., Schnier, C. H., Siewers, H. O. (1977). Trace elements in mussel Mytilus edulis from coastal areas of the North Sea and the Baltic. Multielement analyses using instrumental neutron activation analysis. J. Radioanal. Chem. 37: 927-943

Lande, E. (1977). Heavy metal pollution in Trondheimsfjorden Norway and the recorded effects on the fauna and flora. Envir. Pollut. 12: 187-198

Levi-Setti, R., Chabala, J., Wang, Y. L. (1988). Aspects of high resolution imaging with a scanning ion microprobe Ultramicroscopy 24: 97-114

Mertz, W. (1969). Chromıum occurrence and function in biological systems. Physiol. Rev. 49: 163-239

Noël-Lambot, F. (1976). Distribution of cadmium, zinc and copper in the mussel Mytilus edulis. Existence of cadmum-binding proteins similar to metallothioneins. Experientia 32: 324-325

Nriagu, J. O., Pacyna, J. M. (1988). Quantitative assessment of worldwide contamination of air, water and soils by trace metals Nature, Lond. 333: 134-139

Qutrequin, M., Bernard, J. L., Inglebert, R. L. (1988). Detection limit optimization in the new MIQ 256 microprobe. In: Benninghoven, A., Huber, A. M., Werner, H. W (eds.) Secondary Ion Mass Spectrometry SIMS VI. John Wiley and Sons, New York, p. 165-168

Papadopoulu, C. (1973). The elementary composition of marine invertebrates as a contribution to the sea pollution investigation. Proc. Mambo meeting, Castellabate, Italy p. $1-18$

Petemac, B., Legovic, T (1986). Uptake, distribution and loss of chromium in the crab Xantho hydrophilus. Mar. Biol. 91: $467-471$

Pickering, Q. H. (1980). Chronic toxicity of hexavalent chromium to the fathead minnow (Pimephalus promelas). Archs envir. Contam. Toxic. 9: 405-410

Plaskett, D. Potter, I. C. (1979). Heavy metal concentrations in the muscle tissue of 12 species of Teleost from Cockburn Sound, Western Australia. Aust. J. mar. Freshwat. Res. 30: $607-61.6$

Price, H. A. (1983). Structure and formation of the byssus complex in Mytilus (Mollusca Bivalvia). J. mollusc. Stud. 49: $9-17$

Pujol, J. P. (1966). Le complexe byssogène des Mollusques bivalves. Histochimie comparee des sécrétions chez 
Mytilus edulis et Pinna nobilis L. Bul. Soc. linn. Normandie $10(8): 308-332$

Read, P., Read, E. (1972). Phagocytosis in Invertebrates. II. The clearance of carbon particles by the cldu Tridacna maxima. Res. J. Reticuloendothelial Soc. 12: 349-360

Riley, J. P., Chester, R. (1971). Introduction to marine chemistry. Academic Press, New York

Riva, M. C., Flos, R., Crespi, M., Balasch, J. (1981). Lethal potassium dichromate and whitening (Blankophor) exposure of goldfish (Carassius auratus): chromium levels in gills. Comp. Biochem. Physiol. 68C: 161-165

Sastry, K. V., Sunitatyagi, M. (1982). Toxic effects of chromium in a freshwater teleost fish Channa punctatus. Toxic. Lett. 11: $17-21$

Schulz-Baldes, M., Rehm, E., Farke, H. (1983). Field experiments on the fate of lead and chromium in an intertidal benthic mesocosm, the Bremerhaven Caisson. Mar. Biol 75: $307-318$

Schwartz, K., Mertz, W. (1959). Chromium (III) and the glucose tolerance factor. Archs Biochem. 85: 292-295

Smeathers, J. E., Vincent, J. F. V. (1979). Mechanical properties of mussel byssus threads. J. mollusc. Stud. 45: 219-230

Strik, J. J., De Longh, H. H., Vanrijn, J. W., Wuite, T. P. (1975) Sublethal effects of toxic chemicals on aquatic animals Elsevier, Amsterdam

Sunila, I. (1987). Histopathology of mussels (Mytilus edulis)

Responsible Subject Editor: Dr A. K. Sparks, Seattle, Washington, USA from the Tvärminne area, the Gulf of Finland (Baltic Sea). Annls zool fenn. 24: 55-69

Unnlü, M. Y, Fowler, S. W. (1979). Factors affecting the flux of arsenic through the mussel Mytilus galloprovincialis. Mar. Biol. 51: 209-219

Van der Putte, I., Brinkhorst, M. A., Koeman, J. H. (1981). Effects of $\mathrm{pH}$ on the acute toxicity of hexavalent chromium to rainbow trout (Salmo gairdneri). Aquat Toxic. 1. 129-142

Van der Putte, I., van der Galiën, W., Strik, J. J. (1982). Effects of hexavalent chromium in rainbow trout (Salmo gairdneri) after prolonged exposure at two different $\mathrm{pH}$ levels. Ecotoxicol. Envir. Saf. 6: 246-257

Viarengo, A., Moore, M. N., Pertica, M., Mancinelli, G., Zanicchi, G. (1985). Detoxification of copper in the cells of the digestive gland of mussel: the role of lysosomes and thioneins. Sci. total envir. 44: 135-145

Waite, J. H. (1985). Catechol oxidase in the byssus of the common mussel Mytilus edulis L. J. mar. biol. Ass. U.K. 65: 359-371

Young, D. R, McDermott, M. (1975). Trace metal in harbor mussels. A. Rep. S. Calif. Coast. Water Res. Proj., El Segundo, California, p. 139-142

Zaroogian, G. E., Johnson, M. (1983). Chromium uptake and loss in the bivalves Crassostrea virginica and Mytilus edulis. Mar. Ecol. Prog. Ser. 12: 167-173

Manuscript first received: December 28, 1988

Revised version accepted: July 6, 1989 